14 


RANDOM CASTS

Odds and Ends

From an Angler's Note Book.

$$
\text { NEW YORK : }
$$

DERBY BROTHERS, PUBLISHERS,

27 Park Place.

$$
\text { I } 878 \text {. }
$$




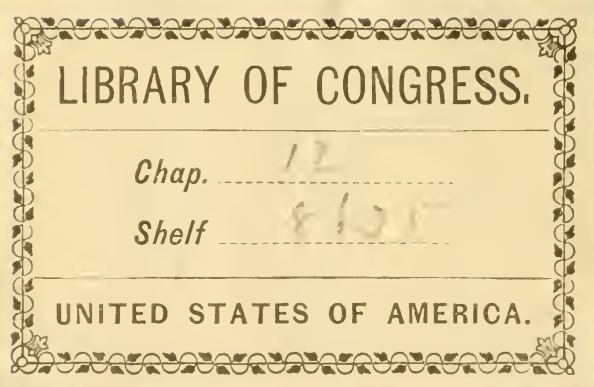




\section{RANDOM CASTS;}

OR

\section{ODDS AND ENDS}

From an ANGLER's NOTE BOOK,

BY
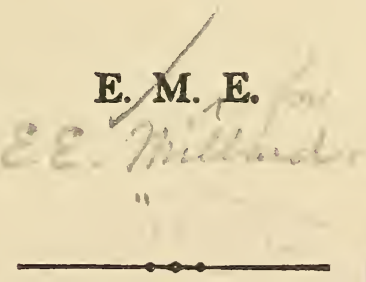

NEW YORK:

DERBY BROTHERS, PUBLISHERS,

27 Park Plack.

$$
5878 \text {. }
$$




\section{SH44I \\ - M 64}

Copyright by Derby Brothets,

1878. 
TO MY FRIEND,

\section{CHARLES M. GRAVES, TEIS LITTLE VOLUME}

AFEECTIONATELY INSCRIBED. 

"Oh! the sweet contentment,

The countryman doth find !

Heigh trolallie, lolle lee,

Heigh trolallie, lee.

That quiet contemplation

Possesseth all my mind.

Throw care away,

And wend along with me."

\section{Waltor}





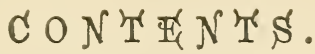

I.-Dogs. Catching one. Ride to Morehouseville. At Becrafts.

II.-Memory and Hope. A Fairy Story. The Angler's Sabbath. Regular Habits.

III.-Guides. Spruce Lake. Solitude. On a Raft. First Day's Fishing.

IV.-Early Rising. A Contrary Wind. The True Angler. A Trout Fight. Wilgus.

V.- - First Things. My First Trout. A Leaky Shanty. Wilgus and the Panther.

VI.-In the Woods. Pleasant Companions. A Summer's Nooning. A Pipe of Tobacco.

VII.-Jessups River. Wet Feet and Tight Boots. Creek Fishing. Loosing a Trout. Suicide.

VIII.-Down the River. Pretty Things. A Quixotic Attempt. Discharge of Wilgus. 
IX.-Sunrise. The Old Whisky Bottle. Strategic Angling. Life and the Stream.

X.-A Warm Tramp. The Upper Stillwater and High Falls. Our Shanty. A Long Night.

'XI.-No Luck. Black Flies and Musquitoes. A Short Lecture. Pictures in the Fire. "Gluck Auf."

XII.-Snoring Sunday Morning. The Haunted Church. Dinner.

XIII.-Sabbath Breaking. Night up a Tree. Forest Lessons. Fly Fishing. Good Night. 


\begin{abstract}
CHAPTER I.
DOGS-CATCHING ONE-RIDE TO MOREHOUSEVILLEAT BECRAFT's.
\end{abstract}

๑EMARKS our fat friend Senior: "It is a saying old as yonder hill that you cannot teach an old dog new tricks, but $I$ intend to demonstrate to your entire satisfaction, gentlemen, that they can be taught to dispense with the performance of some of their old ones."

Says Grey: "I have no idea, my well fed friend, that your remarks have a personal application to any gentleman of our party, and although the shoe does not fit me, still, you have aroused a little of my latent curiosity and I will relieve my anxiety by asking what is the meaning of your very commonplace affirmation."

" Had you ridden or driven over the road we journey to-day as many times as I have, your curiosity would not have been irritated to the extent of dubbing my remarks as commonplace. Still, I forgive you my boy, as I well know your 
kindness of heart overbalances many times the infirmities of your temper." .

This, at Ned Williams' well kept hostelry at Forest House, one day in early June. A party of fishermen were on their way to Hamilton Co., for a couple of weeks trout fishing. Senior had just returned from a foraging expedition in the tavern kitchen and disclosed as a successful result of it, a large piece of raw beef. As he explained the disposition he intended to make of it, his eyes plainly said:

"Mischief thou art afoot."

his nose suddenly attained a scarlet rubicundity, which Bardolph might well have looked upon with envious eyes and his cheeks saw the beacon light and passed its warning up to his forehead, which in its turn signalled the bald spot on his crown. It was not the modest blush of maidenhood, nor the roguish flushing of harmless deviltry, but the glowing earnestness of impending revenge. The way the red blood flashed up and went its rounds was a living illustration of the beacon lights of the old Anglo-Saxon times. Having reached headquarters and performed its mission, it gradually subsided leaving the full 
moon face of Senior looking as childlike and innocent as a South Down.

At a farm house on the road leading north from Forest House, was a dog that for many a long day had been the terror of little boys and girls and for excursions innumerable, the annoyance of hunters and fishermen, for no party of mirthful disciples of Nimrod or of Walton could drive past the gate where he kept watch, but the ugly brute almost invariably made an attack in the rear, following until he had made himself hoarse, and made the air fairly ring with his deep gruff gutterals. None had dared to shoot him, as the report of a gun would have surely detected the shooter, so every one who chanced to be an object of the dog's dislike, was obliged to grin and bear it; but a day of retribution was coming, a day of sorrow for our noisy. barking enemy.

There is no truer more devoted friend to man than a dog; there can be no greater enemy when they have sufficient cause, for their memory of good and bad treatment rarely forsakes them, but for what reason this overgrown shaggy specimen of the canine species should cherish to- 
wards us such a warlike feeling was beyond our comprehension, for, as Logan said of the pale faces :

"We never did harm to him."

The dog is said to be capable of correction and if he possesses the faculty of reasoning, as is claimed for him, a wholesome lesson imparted to him may be for his good, teaching him that it were better to be a gentlemanly dog in appearance at least, even if

$$
\text { " He may smile and be a villain still. }
$$

Senior had prepared a stout linen line with a No. 9-0 Limerick hook baited with a tempting piece of beef, rich, red and rare enough to tempt an epicure. As we drove past, the old enemy came dashing towards us, giving assurance of the belligerent spirit within him, by a series of deep roaring growls, but a peace maker catches his eye, the voice for a moment is hushed, and with one savage spring the hidden steel is in his jaws. Tige, Fido, or whatever his name was, had evidently fasted. A jerk from Senior, fastened the hook, a sting of the whip, from Grey, starts the horses to a keen jump and the way that dog straightened the line was a caution 
even to shark fishermen. Away we went like Tam O'Shanter, with the witches after him. Senior by no manner of means evinced as much patience and forgiveness as Newton did towards his little dog Diamond, when he tumbled Sir Isaac's mathematical papers into the fire, and received as his punishment only a word gently and sorrowfully spoken. Senior's disposition on the present occasion was the other extreme, for he gave utterance to the satisfaction he felt in a manner more emphatic than elegant, and now that he had his ancient enemy in his power, he was going to cancel the debt and have a balance due him. Away we went. How the dust did fly and how that dog did travel and scratch gravel for one good mile, belching forth meanwhile a perfect tornado of discordant tortuous sounds.

"Revenge is sweet," so saith the poet, but even the spirit of revenge, deep-seated as it was within us, could no longer endure the torturing howls that pierced our ears, so the line was devided and the dog returned as fast as did the schoolmaster of Sleepy Hollow, when the headless horseman followed him from his visit to the 
fair Katrina. He returned with hook and line sad memorials of his greediness and bad temper, returned we hope a wiser and better dog. If not a better dog, he was assuredly a wiser one, for since our catching him he has not been known to disturb the peace of the harmless, but on the approach of a party he may be seen like the solitary horseman of the novelist, wending his weary way towards the barn or around a corner of the house.

There are four of us bowling along in the wagon. First Mr. Senior, the oldest and the fattest of the crowd, as jovial and honest a man as ever broke bread or emptied a glass. Unlike Shakespear's sixth age of man

"With spectacles on nose and pouch on side Iis youthful hose well sewed a world too wide, For his shrunk shank."

he was more like Mouter Van Twillen, about five feet six in height and six feet five around his principal organ of digestion, which protruded like the bay window of a house. It was always a surprise to strangers to see so clumsy looking a man tramping through the woods, or wading trout streams. He was jolly as he was fat, and 
pleasant words were continually tumbling over each other as they fell from his mouth.

Mr. Grey, a fractional part of Senior, as regards age or avoirdupois, for Senior beats him nearly two to one either way-but Grey can distance him casting a fly or playing a trout. Grey is a thoroughly experienced sportsman, who has dropped prairie chickens in the West, duck in the South, fished in the Adirondacks, among the Thousand Islands of the St. Lawrence and among the mountain streams of West Virginia, Colorado and the Eastern States. A lover of good living, he always makes the best of everything and strings dull care and bad luck up by the heels and his example is usually, as it invariable should be, contagious.

Mr. Gould, yet in his noviciate as an angler, but taking to it as naturally as a duck takes to water.

Mr. Storm is an odd sort of fellow, who indulges his fondness for fishing whenever he has an opportunity and sometimes oftener, Sundays excepted. He is in just the company he likes and bound to have a good time at the sport he loves best of all. 
Our horses sped nimbly along as if imbued with our own joyous spirits; the rattle of the wagon startling the chattering squirrels and away they scamper to the topmost branches of the tall trees and peep down with curious eyes upon the noisy load below. Robins, field-sparrows, meadow-larks dart out from their nests in the grass or on the trees. A whole season of song and sunshine is before them and they make the air trill and pulsate with volumes of tenderest melody. Over murmuring streams, past blossoming gardens, rich pastures, fine meadows, greenest glades, orchards dropping in silent showers the delicate pinky apple-blossoms and strewing the emerald sod with fragrance, shaded cottages with flower laden vines climb. ing over their sides, now catching momentary glimpses of the distant mountains as we pass from beneath the many shade trees or rise some hillock in the road. Everything on all sides and in the sky above foster the hope that there are days of pleasure in store for us.

Twenty miles over a fair country road, brings us to Ohio City. Beyond this there is only one rough bad spot in the road, but that spot ex- 
tends about sixteen miles, the entire distance to Becrafts. Positively shocking, patent-leathers would say. It is much better that the road is so difficult and fatiguing, else the place would be overrun with so-called anglers who are too indolent and delicate to endure a rough wagon ride. The hills and rocky roads protect many a poor trout: but for a person who loves a little variety in travel, there is a certain charm in this slowly climbing up steep hills, rumbling over rocks, fathoming deep ruts, jolting over corduroy roads and dashing pell mell over rickety bridges.

Excepting with Senior our avoirdupois had been materially reduced by the perpetual shaking we had undergone since leaving Ohio City and before Becraft's was reached. Little matter how tired one may feel at the end of the journey, the hearty welcome and cordial greeting Mrs. Becraft extends is perfect repose. If you arrive immediatedly after breakfast, she will start another in almost no time. So with dinner, so with supper. If in the middle of night you arrive, you will find the latch string hanging outside. Pull and enter. You cannot take her by 
surprise, and while you remain beneath her roof you are at home.

Good landlords and landladies, like poets and anglers are, "born not made," and this one is of Nature's own moulding, born for the business of taking care of wandering humanity. Not one of that numerous class, who give short answers with an air of magnificent importance, but one who receives and listens to you with cordial and unaffected hospitality. It is one of the places where a stranger can enter, sling his hat in a corner and make up his mind that so long as he conducts himself like a true angler, the best in the house is his and welcome.

The house itself is a substantial one, built by honest day's work. No contract about it. There is no fragility and gingerbread ornaments defacing it. It partakes rather of the strength and cohesion of a tough beefsteak. The inter, nal establishment was stamped with the monogram of thrift, abundance and neatness, and had one feature peculiarly acceptable to Senior, for he is in stature considerably below the average of mankind, and that was, the chairs were adapted to the length of the legs attached to the bodies 
of the visitors. There was not offered to the little man, barely measuring five feet, a chair high enough for the six footer, but every man could find a chair to fit him.

"Oh! that all landlords and landladies," said Senior, "were as considerate; Oh! that all chairmakers felt that short men had rights which tall men were bound to respect. Oh! that all of them had some regard and thought for the poor fellows whom their Maker had afflicted with short legs, and not oblige them to set sideways on high chairs and swing one leg in the air."

\section{CHAPTER II.}

"The first men that our Saviour dear,

Did choose to wait upon him here, Blest fishers were, and fish the last

Food was that he on earth did taste;

I therefore strive to follow those, Whom He to follow Him hath chose."

WALTON.

"Take my advice and let the trout alone on a Sunday, and become fishers of thought, drawing bright and good things out of the depths of memory. They will rise to your cast with great freedom, and take hold strongly and it is a pleasure to land them, and once secure they become an enjoyable posses. sion."

W. C. PRIME. 
Memory and Hope-A Fairy Story-The Angler's Sabbath-Regular Habits.

HEERE we are once more near the old familiar fishing grounds. With what ecstacy of joy does one look forward to a renewal of his acquaintance with rod and line. How often when the ermine snow covers the ground, when the long winter evenings are joyless and dreary, do you think and speak of the many days of pleasure, passed among the sparkling gems and dancing streams, where the lovely trout disport, building airy castles as you look lovingly forward to the spring sunshine, when the snow begins to melt on the mountain tops and countless streams seek the level of the lakes and large rivers; when the Ice king, who for months has sealed the babbling brook, the mountain torrents, the placid lake, the wide river has unwillingly released them from his freezing embrace, when all running streams tripping gaily and coquettishly along offer you their bounties of golden glories.

Memory when she recalls pleasant scenes, faces and thoughts and Hope, when she points the finger of promise towards the future, sweet- 
en the cup of life. Memory has enshrined no brighter thoughts than of the hours whiled away on the wood girdled lakes, on the shady banks of prattling brooks, by mossy rocks in shy little nooks, where the air we breathe is purest, the sky above the clearest, the water with which we quench our thirst, so clear, cold and sparkling, that one becomes even oblivious of his customary lager; the moss and grass on which we rest our weary limbs, the softest, where through the emerald leaves of the forest trees the gentle wind breathes the saddest, sweetest music, the feathered songsters pour out their untaught melody; where you can indulge your thoughts and fancies in a thousand devious wanderings, where the mornings come early and the evenings tarry late, and you look only on the bright sunny side of life, for the while unconscious that there is such a thing as sin in the world, and all heedless of old Father Time, with his scythe and hour-glass, your surroundings are suggestive only of the pleasantest of pleasant thoughts.

When far removed from these scenes, hemmed in by the high walls of a city, how often does 
memory revert to them, making you pant for the wild breath of the mountain air. If you are no lover of winter and are gloomy from impatience to live over again the experience of your lake and forest life, there stands Hope, smiling at and saying to you, when the April sun and showers have softened the earth, starting the fresh buds and trees to new life, inviting the birds from their Southern homes-it is then you may promise yourself a speedy realization of your fondest desires. You may promise your eyes, sights beautiful beyond description; your ears, the welcome sounds and voices of the forest-bird-music, murmuring waters, sighing breezes; your lungs, the wild mountain air ; your cheeks, a ruddy glow; and above all these, the gentle art of Walton, you may practice from dewy morn till rosy eve.

This is Sunday, and Monday morning seems a long way in the future, and the question uppermost in some of our minds, is whether we would be doing wrong by fishing on Sunday. Grey thinks we have no possible excuse for so doing. Grould does not believe fishing on that day is any more productive of evil than dawdling 
the time about the house reading old papers and novels, putting fishing tackle in order, smoking and yearning for Monday morning. Storm would not as a general thing fish on Sunday, nor remonstrate with one who did, and Senior told the following story:

Once upon a time-as the fairy stories begin -four fishermen were sitting on the banks of a trout stream. The day was such an one as this, which cheers and gladdens the angler's heart; but it was Sunday, and these four young men, being law abiding and Sabbath keeping, could not find it in their hearts to cast the fly nor drop the bait among the well stored ripples. After a long and animated discussion, the chief speaker drew from beneath his coat a rod and jointing it, held it over the water at the same time asking if there was any law prohibiting his holding that rod in such a position on Sunday.

"No! no! certainiy not;" the others replied. The second man drew form his pocket a line and fastering it to the end of the rod asked if there was anything detrimental to strict morality in his so doing.

"To be certainly not;" was the answer. 
The third man drew forth a hook, inquiring it his attaching it to the end of the line was a punishable offence.

"No! no! no!" was the chorus and on went the hook. Young man, the fourth wished to know the opinions of his companions regarding the right and wrong of baiting that hook, and being assured that he was violating no commandment in simply fastening a worm on a hook, providing such worm had been dug the day previous and such being the date of its capture, on it went to the secret satisfaction of all.

The rod, line and hook were in complete fishing order and in the hand of the first young man, who then wished to learn the opinion of the party, in relation to a number of points, for they were very moral young men, were these four and would have scorned to go a'angling on the Sabbath day. He wished to know if it would be violating the eighth commandment should he move down the stream to a shady place by yonder rock and by merely dropping the point of the rod, allow the worm to sink a little beneath the water and protect the poor 
thing from the heat of the sun. Of course anything so charitable as that, could not be wrong. There were a great many nice points decided as satisfactorily as these on shore, but the fishes below entertained different opinions and refused to bite, so not one rose to the surface.

Fearing a repetition of the bad fortune attending these moral young men who went fishing on Sunday, and the majority of us being or rather inclined to be conscientiously opposed to it, we returned a verdict of served 'em right, and postponed our fishing until the proper time.

There should be no question as to the proper way of spending the Sabbath day. "You three big lusty fellows," says Senior, "have you nothing to be thankful for? You Grey and Grould have health and strength and manly beauty, and seriously how often do you return thanks for them? I beg pardon Grey, for tacking you and Gould together in that manner, for I know you are incapable of disobeying the commandment which says: "Remember the Sabbath cay to keep it holy."

You Storm, have health and strength and although you do not handsome by the wholesale, 
you have more to be thankful for than you can repay. Stay at home and "think and thank." I know there is nothing in the whole wide world half so beautiful, as a well conditioned trout, but were it a thousand times better and more beautiful, more beautiful and blessed is the Sabbath day's rest. If angling is the "contemplative man's recreation," let this be a day of contemplation and spend it "without harm to your souls or interference with the rights and enjoyments of your fellow men." I do not propose to sling the concluding lines of Bryant's Thanatopsis at you, but please read them the first opportunity you have and then live up to them.

Even if it proves to be a tame day, none of us will have the blues while Senior is present, for he is a man who never keeps down the devil of harmless and innocent fun, but lends him a helping hand, and the blue devil would find little about him to warrant a long tarry. Agreeable friends are blessings and he is one of the most attractive of those blessings, of cheerful temper, good humor, good sense, a prince among good fellows. A lover of nature finds much to love 
in one as fond as himself of the woods and waters. There is a marvelous free-masonry in the forests, a mystical, indefinable sympathy, drawing men mysteriously towards each other. Sympathy is a jewel, one of the pearls of life, and perhaps that is the secret of the mutual liking existing between Senior and Storm, for, aside from their love of the woods there is no resemblance between them.

With all of Senior's pleasantries the day to Gould seamed inordinately long. He had soon exhausted the scanty library and never did a man more want to discount the next few hours.

"It's all right sonny. Take an old man's advice about the Sabbath day and you'll make no mistake. If you think I am old fashioned and in my dotage, next Sunday you may have your own way and not a word will I utter in opposition, and then we'll see how you like it. This evening we'll go over the creek to Wilgus, and get him to back a load to the lake and help Giles around the camp. He used to be a decent sort of fellow if you kept whiskey away from him, and stood over him with a club. Naturally lazy, he will bear a great deal of 
watching and stands up under any amount of tongue lashing."

"I do not see the sense of engaging such a man as that."

"He will amuse you. His stupidity and lazyness will give employment to your cardinal virtues, which, I guess, are rather rusty."

"Mr. Senior you have hitherto borne the reputation of being a level-headed man, but what can possess you to hire such a leatherheaded old mummy as you say Wilgus is, beats my time."

"I tell you, you will have some fun with him."

"He'll be the principal attraction in a funeral procession if he runs foul of me with any of his infernal nonsense."

"His barefaced lies will amuse you, and on that account you will shake hands with him and greet him as a brother."

"Supposing I were to greet him as Cain greeted his brother Abel, would you not justify me? At any rate, I do not purpose to have my sport interfered with by any whiskey drinking old fraud like your friend Mr. Wilgus."

After an early supper Senior and Storm callec. at Wilgus'. 
"Good evening Mrs. Wilgus, and how have you been this many a month since I last saw you."

" Why, bless me, Mr. Senior, but you are good for my poor old eyes. I am very well, and you seem to be growing shorter and stouter and redder year by year."

"Oh! that's from leading a quiet, regular life, temperate in every respect."

"Well, Mr. Senior, regularity, in one's habits, goes far towards prolonging one's life and happiness, There's me and Wilgus for instance. We never have got along so smooth as during the last four years, since he commenced to be regular in his habits."

"Seems to me, Mrs. Wilgus, that John is getting very irregular in his habits, in his old age."

"Why, bless you, he has never been so regular since we was man and wife."

"He has a mighty queer way of showing it then."

"I don't see anything irregular about him. You can depend on him as much as you can on the rising of the sun."

"I saw him at Morehouseville, yesterday, and he did not look that way." 
"That's just where you make a mighty big mistake, young man, and don't forget it. He came home late last night, drunk as a lord, just as I expected he would, and that's the way always with him. A few years ago he would come home, sober most of the time, but occasionally a little off color. Finally he got so I could not tell how he would turn up, but now he is regular as you could wish-regularly drunk you can depend on it, and that's what suits me, I always know how to find him."

"Can you spare him for a few days and let him go up to the lakes with us?"

"Yes; send Giles over for him early in the morning, and I'll have him fixed up. He ain't got back from the Ville yet, but he'll be around all right and don't whiskey him up too much when you get him in the woods. Keep him jest so, so." 


\section{CHAPTER III.}

"Blest silent groves, oh! may you be

For ever mirth's best nursery!

May pure contents

For ever pitch their tents

Upon these downs, these meads, these rocks, these mountains,

And peace still slumber by these purling fountains ;

Which we may every year

Meet when we come a fishing here."

Sir Henry Walton.

"Just one more cast, I yet can see

That miiler's white and dainty wing.

Hold! there he comes, strike quick and hard,

Oh! don't he make that leader sing.

He's doubling on you, look out, sir !

He knows the game, just see him cut!

I'll risk my rod to save that trout,

Stand by now, Frank, he's got the butt."

Guides-Spruce Lake-Solitude-On A RafT-

First DAY's Fishing.

HIAVING disposed of a hearty Monday morning breakfast, to the merits of which we did ample justice, we re-arranged our baggage, putting it into carrying shape. We are going to Spruce Lake and Giles Becraft is our guide. 
Very fortunate is that person who has secured the services of a good guide, and his lump of gratitude must be undeveloped if he does not thank his lucky stars. The woods are swarming with men who call themselves guides, but few are deserving of the name. The first-class guides always designate those frauds who try to earn an odd penny, by claiming some knowledge of wood-craft, as farmers.

They can chop wood, carry a moderately sized load, but as for performing any of the functions appertaining to wood-craft, one might as well engage the service of a tobacconist's sign. Their short comings in knowledge and experience they strive to neutralize by pretense and swagger. They will make any kind of statement and confirm it, by sticking to it, which, four times out of five is the only confirmation it ever receives.

Giles is a genuine unadulterated back-woodsman, none better, few so good, and not like too many of his class who are as difficult of solution 
as one of Euclid's problems would be to the average Digger Indian. Guides usually have a dark mysterious look and manner, seldom vouchsafing any of their wood-craft to outside barbarians, as though telling north from west on a cloudy day, was an imposibility save to those born and educated in the forest, while the faculty of detecting intricate and hidden trails transcends the acquirements and capacities of ordinary mortals. From what few words they condescend to address to you, you must draw your own inferences, for seldom will they enter into details.

Giles is not one of that class. All his knowledge is like himself, at your service. Not old in years, he is old in experience; proficient in the use of the rifle, the rod and the paddle, so familiar with every trail through the woods that he never has to put on his spectacles, and what is better than all, he has nore of the vices so prevalent among men and which in a great measure accounts for his strength and activity. $\mathrm{He}$ 
is agile as a buck of the forest, tall, broad shouldered, ample chested, well muscled, easy tempered, good natured.

The tramp before us to Spruce Lake is no easy one. Pedestrianism in the woods is awkward and floundering. Who can catalogue the almost inexhaustible variety of impediments that $\mathrm{Na}$ ture has interposed to prevent comfortable locomotion? Every rod presents its specialty, and a mile would furnish a list appalling to the strength of any not a thorough devotee to the sport, offered after the difficulties in reaching it had been surmounted. Then the length of a mile according to the North Woods Guess Measure is

I4 inches make............. I foot.

$3 \frac{1}{4}$ feet $\quad$ " . . . . . . . . . . . I yard

6 yards " $\ldots \ldots \ldots \ldots \ldots \ldots . . . . .1$ rod. 400 rods

We fear that the majority of American anglers much prefer a well beaten track, even if it leads to waters too well fished to return them a good dividend on their investment. Those 
who follow us will have to use their legs. A man who has an aversion to climbing and tum bling and torn clothes, never comes this way but once. He never passes his plate the second time for a day's tramp.

Eight hours after leaving Becraft's, and about the middle of the afternoon, our packs are unslung at Spruce Lake, and a welcome we receive from birds, squirrels and rabbits, for we are old acquaintances of their parents, who have brought up their children to fear us not, as we think they are very pleasant to have running around the shanty, and none of us would harm a hair of their backs or a feather of their wings.

The North Woods are full of beautiful lakes and ponds. Morehouse, Big Rock, Little Bear, Pine, G, have many attractions surrounding them, but our idea of a beautiful lake is Spruce. Larger than the others, its surroundings, its shape, its conveniences render it the pleasantest and most enjoyable in this region. $T_{t}$ has the finest outlet of all; not an abrupt tumbling over 
the shore, but a wide stream carrying its surplus waters away to the Canada Creek.

The woods are never more than merely lonesome, for we hear the drumming of the partridge in the distance, the "who! who! whowho-O-O-O" of the owl, the tapping of the woodpecker, the notes of the blue jay ; but it is by some stream or lake that one realizes, to the fullest, what is meant by solitude. The voices of the woods detract from the feeling of lonesomeness, but by the lake those other voices and views, the quack of the ducks, the sight of a deer feeding in the lily-pads, the plash of an oar, and that sound, more suggestive than any other of utter loneliness, the shrill cry of the loon only serve to intensify the sense of solitude and make it more solid. Water adds to its solidity.

If there was any way of transportation, this lake solitude might be cut into blocks, taken to the large cities and disposed of at remunerative prices, for no family especially where there were children would be without one; what a blessing 
to the wearied down-town man who has been in a push, rattle and jam since morning could he, when returning home in the evening, ensconce himself in his block of solitude. "There's millions in it," for the man who will devise some method of getting it out of the woods.

When Alexander Selkirk said :

"Oh! solitude where are the charms,

That sages have seen in thy face."

He must have been gazing seaward. Alexander, however, had become surfeited. He had got too many oats for a shilling. His cup of solitude was full to overflowing, and doubtless he would have tolerated anything for a change.

One very interesting feature about these lakes is the rafts. The tortoise has been quoted as an illustration of slow travelling ever since the days of Esop, but had the great fabler ever been made to work his passage on a raft, the tortoise would not have figured in his writings. The hands of a clock can be seen moving around the dial in obedience to the mechanism within. 
If your vision is very acute and your watching patient, you may see the corn growing, the hops slowly climbing up their poles, the flowers unfolding their beautiful petals, your boy growing day by day, until his stature exceeds your own; but how you can distinguish, appreciate, or be conscious that any raft you are poling or paddling is making headway, is a problem that our senses, wood-craft or water-craft, as yet fail to solve.

The slang expression, "go slow old man and learn to paddle," was first spoken to a man on a raft. It was a speech totally unnecessary, for the poor man had no alternative but to go slow, and the fellow who delivered the insulting speech knew full well that if it were taken unkindly, he could leisurely beat a retreat and be miles away before the man on the raft could effect a landing and chastise him for his insolence. "Hurry up," says Grey, while we are preparing our lines, flies, \&c., "be out on the lake as soon as you can, for it smells trouty 
enough this afternoon and make a note of what I say, we will have all the trout we want to bring to the shanty this blessed night."

In the east it was clear, a slight rifple was on the water, everything indicative of good sport among the fishes below and for the fishers above, and Grey conclusively demonstrated that he was a true prophet on this occcsion, when he promised us our baskets full of the speckled beauties. No long bearded Mussleman could have placed more implicit faith in futurity than we, after hearing Grey so confidently predict such luck.

The ripple on Spruce is always a favorable sign. Without a breath of air stirring, when the lake lies smooth as a mirror, it is folly to try and tempt a trout to seize the most deceptive and carefully prepared fly. They will laugh at you just as surely as fish do laugh and call their fellows to witness your devices, and then bidding you good morning, hasten gracefully away to their homes and there remain until they hear the breezes above. 
Jaded as we all were, we felt as though a trout supper we must have, so Senior and Gould, on our raft, poled across to the bay, where the Piseco trail strikes the lake, where they were to throw, and Grey with Storm on another raft poled towards the upper end of the lake, where the anchor was dropped just beyond reach of a large tree that had fallen into the water and made their first cast. Grey has sclected a grizzly king, a grouse hackle and blue-winged coach- man, with which to allure the speckled swimmers, and right well did he succeed ; the tempting morsels were too great to be resisted.

"So glistened the dire snake and into fraud

Led Eve our credulous mother."

No sooner had the flies gently touched the water than whiz $-z-z$ sang the reel, the line grows longer and longer, the graceful bend of the rod its whole length, tells plainly as words, that some one of the myriads of trout that inhabit the lake, and one of more than ordinary size, had taken Monsieur fly between his jaws, 
and does not think the morsei improves on acquaintance, for his efforts to free himself are frantic in the extreme. A genuine desperado is this first martyr to our sleight of hand, but a strong line and rod in skillful hands, will ere long land you my beauty and over a blazing fire we will give to your bright spots a golden brown, and hungry men will pronounce you incomparable, but not you alone, for others of your kind will grace our homely table.

Whenever Grey attempts to do anything it is done secundum artem, and this was no exception, for easily he played the trout, checking him gently in his "mad career," giving and taking until the fish resigned the unequal contest and surrendered, while a gleam of joy irradiated Grey's features as he deposited him in his basket.

Storm's first cast was not rewarded. He tried a bright red fly, but it was too flashy to secure the admiration of any trout that day. They are whimsical creatures and like their 
food in season just as men like ice cream and sherry cobblers in July and hot whiskies in January. Substituting flies like Grey's, pleased their dainty tastes, for soon Storm had his attention called to something smaller than a whale which was tugging away for dear life, trying his prettiest to rid himself of the sharp pointed steel he had so greedily taken.

Come in out of the wet; never more if my line don't part, will you glide through the bright waters, frightening the smaller fry and verdant chub that frolic in the shallow shore waters. Bigger chubs than they await your coming, smacking their lips in expectation of the treat you will afford. Your rich flavor will tickle our palates to-night, as we gather around our huge log-fire.

Hallo! somebody else is knocking at the door. Well! come in, we salute you, we are all at home this blessed day, ready to receive calls and visits from such as you. Please come in. Excuse our slouched hats and heavy shoes. Do 
not judge us from outward appearances. Rough our exterior, but there are kind hearts beating beneath our wood-worn coats, and we will treat you kindly, for we love you best of all swimming things, and yours shall be a nice warm. corner of the frying pan and our ears will listen with pleasure as you sing your last song with the cracking of burning logs about you. How you will writhe and twist dear fellow, how you will writhe and twist. Still another and another. They cannot be frightened away. Oh! poor deluded creatures, how we pity. We are the spiders,

"Will you walk into my parlor, Says the spider to the fly."

But never more can you return to your old homes. The tracks to our creels are like those before the lions den, all pointed in, none out.

Tempus never fugited faster than he did this afternoon, but he could not distance us, and ere the katydids commenced their evening songs, we had nearly filled our baskets and returned to the shanty. 
In the frying pan was placed a portion of the afternoon's catch, and under the watchful eye and skillful hand of Giles, they underwent a complete metamorphosis, their spotted sides and graceful forms, changing to a golden brown and curling up as they hissed over the fire. Senior superintended the making of the coffee, hot, strong and plenty of it, while Gould and Grey set the table, a large piece of bark, and covered it with miscellaneous edibles. We had tin plates with us, but nice broad chips made better ones, obviated the necessity of washing, and when we were through with them, they made famous kindling wood. Everything is ready, help yourself.

A smoke, a rubber of whist, and then winding our blankets around us, we were soon sleeping and dreaming dreams that made the long night seem as bright and cheerful as the sunshine of life. 


\section{CHAPTER IV.}

"The wet leaves, the morning air Are stirring at its touch, and birds are singing As if to breathe were music ; and the grass Sends up its modest odor with the dew, Like the small tribute of humility. Lovely indeed is morning. I have drunk Its fragrance and its freshness, and have felt Its delicate touch; and 'tis a kindlier thing Than music, or a feast, or medicine."

WILLIS.

"Then I gently shake the tackle, Till the barbed and fatal hackle In its tempered jaws shall shackle That old trout, so wary grown. Now I strike him! joy ecstatic ! Scouring runs! leaps acrobatic.

So I angle, So I dangle,

All alone."

Fitz. JaMes O'Brien.

Early Rising-A Contrary Wind-The True AnglerA Trout Fight-Wilgus

$W$ HEN Senior calls you in the morning you must rise ; there is no rolling the blankets closer around you and courting slumber, for his "pile out" is a fiat from which there is no appeal, so we are up with the dawn. 
"Throw up the window ! 'tis a morn for life

In its most :subtle luxury. The air

Is like a breathing from a rarer world

And the south wind seems liquid-it o'ersteals

My bosom and my brow so bathingly."

I Early risers can best appreciate a charming day, for they alone behold its greatest beauties, the first blush of morn, when the golden gates of the East are unlocked, and woods, vallies and hills, little ribbons of streams, lakes and rivers, are all bathed in the light. Drink in the perfumed air; the slightly frosted air, burst your lungs with it if you can, bolt it down, it will cause sensations of delight, clear the head, lighten the heart, sharpen the eye, plant roses on your cheeks. It is the best cosmetic in the world. Open your windows, invite its early visits, and billow after billow will come surging in until the whole room is flooded with freshness and fragrance, with inspiring whiffs and invigorating breezes. Be an early riser here if you are not when in the town. Never let the birds summon you from your slumbers more than once. Be up when they are, at the dawn 
of the day. Do not lose the best hours of the twenty-four in effeminate sloth, but be up if you love a charming day ere its loveliest and most charming part has disappeared.

We all bear a hand towards preparing breakfast. Each has his duties assigned to him and the boss of the coffee pot has the most difficult to perform if he does his task properly.

Eolus, the king of the winds, eccentric as he sometimes is, has never had the reputation of being an inebriate, simply because those who know him best have sacredly kept their knowiedge of his worst qualities from becoming a scandal to the gossiping world. But the truth must out. We know him in his gentle moods "breathing o'er a bank of violets," carrying unseen the fragrance of fruits and flowers. We have seen him dallying, like a lover, with the golden locks of sweet sixteen, and acting the good Samaritan to wearied three score years and ten. He fills the spreading canvas over thousands of busy decks and the whole world welcomes his quiet coming. 
We know him in his angry moods, when he uproots the monarchs of the forests, when steeples, roofs and bridges are carried away as though they were paper toys. The ocean and great lakes he lashes until they are white with rage, and in their madness swallow up and destroy the wealth of nations and the lives of those we love. He is grand and mighty in his madness.

That is his reputation with the world at large, but ask the man who has had to superintend the preparing of a meal in the forest, and he will tell you that if ever there was a disagreeable, drunken, dissolute, and detestable devil in the world it is Mr. Wind, especially around a camp-fire, during meal time. $\mathrm{He}$ is enough to drive a saint to the verge of profanity.

You cannot get to windward of him, you are always in his teeth and he is incessantly blinding you with smoke. $\mathrm{He}$ is ubiquitous. We know whereof we speaketh. He has followed us in the most provoking manner, changing his direction for the most unaccountable reasons, in 
fact, for no reason whatever but to be drunkenly mean and disagreeable. He combines the treachery of a Sioux with the persistency and perversity of an empty musquito. That is the plain English of it. That is a true picture of him as he exists, in a place where of all places in the world, he should be a decent fellow and treat his visitors with at least a suspicion of consideration. But that is hardly to be expected at this late day. He is beyond redemption and if, when you are boiling your coffee or frying your trout, he cuts up his capers, as he undoubtedly will, you may indulge in justifiable growls, and if you have an absurd prejudice against profanity, cast it aside, just this once, no more, and wax eloquent in denunciation of the fiend wind and the demon smoke.

After breakfast we paired of, as on the previous day, and all started towards Balsam Lake outlet, on the east side of Spruce Lake, buoyant with hope, joyous and expectant as school-boys with an extra holiday. One can enjoy the an- 
ticipation of pleasure with almost as keen a relish as he does the participation. Hope, that blind Fortune will favor, is one of the secrets which appertain to the sportsman's recreation, be he armed with rod or gun, and Senior pinned his faith on his experience of previous mornings like this. There is a great deal of speculation in 1t, but speculation is a Yankee characteristic and he comes honestly by it. His auguries were not false.

Full in our face was blowing a gentle breeze laden with no blinding smoke, but one of exquisite freshness, not eager, just strong enough " to blow a lady's curl aside," a promising morning, it was fairly burdened with favorable signs.

"I'll forfeit my credit," said Senior, in the art prognostic, "although I am not the seventh daughter of a seventh daughter, that mine is the largest fish to-day.

Says Frank Forester, "the man who fishes for the fish and not for the fishing, is not a true sportsman," and when we cast our flies on the water 
it was not the size and value of the fish that prompted the casts, but the sport of playing and drowning them in their natural element. We would sooner have a half-hour's struggle with one that fights well for its life, and at last dies gamely or even escapes, than to catch a dozen, in half the time, if they could be landed without an effort.

It is not the number of fish he captures that makes the angler contented, for the true angler can enjoy the mere throwing of the fly if he has only an occasional fish to reward his efforts $\mathrm{He}$ is no profane glutton damning every fish in the water unless they take hold. $\mathrm{He}$ is conversant with their whims and good naturedly humors them. There is something besides catching fish to call him to the woods and waters. Henry Walton said of angling: "it. was a rest to his mind, a cheerer of his spirits, diverter of sadness, a calmer of unquiet thoughts, a moderator of passions, a procurer of contentedness." 
There's a trout taken your stretcher and he's going away with it. Steady now! How your eyes sparkle Mr. Storm; beaming with faith and hope. You're giad enough it's going and it's coming back again if you are only yourself and don't allow your temper to be ruffled nor a nerve shaken. Don't be rash nor boyish, which too often looses the game by first loosing control of yourself. The excitement makes your heart beat as wildly as a girl's upon her wedding morning. Don't get excited, I tell you! better go home and die like a stupid blockhead. Don't swear, for, says good Isaak Walton: "swear not angler, or you'll frighten the fish." Give him a little more play-room, for he insists upon having it. Now don't be in too great haste, there's time enough. Many and many objects easy of attainment are failures from the clumsiness of haste and anxiety. Don't let yourself think you are "standing on the ragged edge despair." Bear in mind the old adage "The more haste the more waste," and take your 
time if it is all day. There he goes again.

Now a steady hand for that's the keystone to success.

If ever a trout thought, that trout was thinking, concocting some mischief. Finally he moved slowly towards and underneath the raft, bending the rod fairly double in his efforts to break it, but it was one of Buckingham's best and nothing save a suddon jerk could break it, and the man at the butt end of it was watching carefully that nothing under the category of jerks should occur.

A trout has a genius for strategy. He is one of those fellows that find out things in which they are particularly interested in a very brief space of time, and this one concluded right speedily, that no steady pull was going to divide the line or splinter the rod, and accordingly he changed his tactics, and broke to the surface, his handsome sides and richer than golden belly shining among the sparkling drops of the tiny shower he caused as he came upward with a 
mighty rush, and again he came and again, each rush as frantic as the first, for full well he knew that "desperate diseases by desperate remedies are cured or not at all," and his remedies were the very embodiment of recklessness and despair. Suddenly he adopted a new artifice to achieve his exemption from the frying-pan, and away he started for the opposite shore. making the reel buzz as the line lengthened yard after yard, but a pull, strong as the fine line would bear, deadened the force of his headlong rush, and back he suffered himself to be led by the nose; but not yet a prisoner as he was still alive though somewhat discouraged. His silent submission was only a new ruse to throw his would be captor off his guard, for while Storm was quietly reeling him in he shot forward so rapidly that the rod had to be carried away over the shoulder to prevent any slack in the line, and the brilliant beauty appreciating the condition of affairs made his final effort by jumping out of the water again; but he was so promptly and carefully 
met that he abandoned the struggle and unconditionally surrendered.

He was stuck as fast to the hook as sin has stuck to the human family ever since Eve was tempted in the garden. Its fierce paroxysms availed nothing for

"Fixed to the teeth by that tough shining bait,

He struggling yields to suicidal fate."

Well, well, caught at last old fellow! dead to all intents and purposes, dead as the mummies of Egypt embalmed thousands of years ago.

Could you see the smile of triumph playing over the features of Storm, the eyes sparkling with exultation, the cheeks flushed with pleasure, you would never have thought his was naturally a cold distant looking face though no true index of the inner man.

While Storm was landing this fish the others had not been idle, for some beautiful trout, ranging from a half to two pounds, were thrashing helplessly in the baskets. 
Wilgus after trying to help Giles around the shanty, and proving himself more of an encumbrance than an assistant, was gladly dismissed by Giles and told to get aboard a raft and try to catch a few fish. Wilgus made the attempt, but at his first anchorage fell asleep, and remained so until Giies finally paddled out for him, brought him ashore, and set him to chopping wood.

Wilgus was decidedly lazy or perhaps constitutionally tired. He always insisted that he was born tired, and inherited his laziness. $\mathrm{He}$ claimed that his father was the old man who threw hlmself beneath a tree one hot summer's day and said "there, damr you, breathe if you want to, I shant."

He was immensely enamored with hard work. Long he loved to sprawl and contemplate it with a wink and a blink, and to prove he was not afraid of it he would lie down beside it like Mrs. Jones' fat boy, and go to sleep and dream pleasant dreams. 
$\mathrm{He}$ may have been perfectly justified in his laziness, for it was work, hard work too, to carry such feet as his. They were awful in their immensity, and a pair of boots fitted to be easy on his bunions were immense in their awfulness. He was originally from Rhode Island, and his reasons for coming here were obvious. $\mathrm{He}$ wanted room to turn around in without stepping into Massachusetts or Connecticut. He preferred citizenship in a State where there was more land to the acre. He never intentionally stepped on a man's corns, but he was always putting somebody's foot in pain. That was in Rhode Island, but here in the North Woods he could sling his feet pretty much as he pleased and harm nobody.

With digestive organs unimpaired, and a mouth which was put on hot and had run all over his face, he was in perfect accord with Sancho Panza in that both believed eating and sleeping to be the greatest of human inventions. 


\section{CHAPTER V.}

Phys.- "Auche Io sou Pescatore-I too am a fisherman-a triumph."

Sir Humphrey Davy.

"' $T$ is delightful the trout to ensnare, To gaze on his sports, like the cheek of the fair And sigh when their brilliancy sinks in decay, As bright as the rainbow, yet fleet as its ray."

ANON.

\section{First Things-My First Trout-A Leaky Shanty- Wilgus and the Panther.}

SIX men with appetites keen as Damascus razors need a more than ordinary supper to satisfy their cravings, and thanks, we have the wherewithal to supply ourselves. The coffee was delightfully hot, the water deliciously cool, the trout in their golden coats looked tempting enough for an epicure, so

\section{"Down we sat}

And to our viands fell. not seemingly, But with the keen dispatch of real hunger," and we were soon playing knife and fork as industriously as we had done rod and line during the afternoon. 
Our afternoon's sport had been thoroughly satisfactory. None of us could complain, while to Gould it was a real red-letter day in his life. He had abducted his fair quota of the day's catch, and was almost in a transport of joy over his good fortune, particularly admiring and holding up to our gaze, one glorious black-backed, redbellied fellow, the first trout he had ever caught. Gould was tickled enough, and would hardly have cared had he caught no more during our stay. We humor him in his enthusiasm. $\mathrm{He}$ will never again capture his first trout. $\mathrm{He}$ may catch larger trout, but never one that will make his nerves tingle and his heart beat so fast; and though he lives beyond the allotted years of man, through all those years he may often recall the sweetest memories of men and things, his heart will tell him, that save a mother's holy love the sunniest imprint there is this day's pleasure. No success in after life, however brilliant it may be, can efface the memory of it. 
First things usually effect us in a manner peculiarly their own.

Do you remember the first pair of trousers your little legs dove into? Wasn't that a pleasant proud time with you? How proudly you strutted around like a turkey gobbler with that same pair of trousers rolled up to display the red morocco tops of your first pair of boots.

- Well do I remember thu boyish delight I experienced when I ran to exhibit my new clothes to a little girl neighbor. It was soon an old story. Donning them every day the novelty wore away and sliding down cellar doors and down the roof of the old engine house, soon wore away the trousers.

Next came the first cigar with a pleasant sensation, produced thereby, until the middlc of the weed commenced to burn; then came the partial choking, a few tears, a shudder, a gradual unconsciousness, succeeded by a sinking sensation in the region of the stomach, immediately followed by a rising ditto far from pleasant. 
Every good boy has willingly though stealthily, suffered the same disorder. The first cigar however is seldom the last.

Then comes in my experience the first kiss outside of and unknown to my family. Do not mention it for it nearly frightened me to death, but I recovered, and am not a particle afraid of them nowadays. Then I escorted a little girl home and thought myself a little man. My first whipping I do not remember, as it must have taken place at a very early stage of my existence, although the recollections of many inflicted afterwards by parents, teachers, and occasionally by playmates, are as distinctly impressed upon my mind as the cutting, stinging hits were imprinted upon my body. I was considered a bad boy and received many chastisements.

The first trout I ever hooked was at Wilmurt Lake, many years ago. Will Morgan, companion since in many a trip to the woods, was in the boat with me, and had been instructing me in the modus operandi of handling a large fish in case 
I hooked one, and listening to him I had become the least mite nervous. With feelings not at all compassion, I slung the baited hook into the water and presently something walked away with it and a portion of the line while a shout of derisive laughter greeted my ears, thus adding insult to injury.

"O 1 what a tangled web we weave. When first we practice to deceive."

I thought the English language lacking in words strong enough to condemn the lack of sympathy evinced. There was no need of profanity. I did not feel able to do the thing justice, and so I kept a close seal on my lips while an almost overpowering melancholy came stealing over me.

" Be calm, my Delius and serene, However fortune change the scene In thy most dejected state Sink not underneath the weight ;" And when the mischief had been repaired, I dashed away the gloom of ill fortune and boldly said

"I am not sick if Brutus has in hand, An exploit worthy the name of man," 
And at the next venture, quickly mastering the faults of inexperience, I was "born to good luck." How triumphant I felt that moment, and for many after, when that speckled beauty, that golden glory of the water, prince among swimming things, was thrashing helplessly in the bottom of the boat. The dove returning to Noah, with the olive branch, was not more welcome.

With all the manifold pleasures to be derived from a season in the camp, there are many annoyances to be encountered. "The equity of Providence has balanced peculiar sufferings with peculiar enjoyments," and the inverse holds good. Yet in a summer's retreat one ordinarily endeavors to derive as much comtort as possible with the least outlay, and it you are not well up in camp life, and sometime intend giving it a trial, perhaps we can aid you in steering clear of one or two natural discomforts attending it, and like Abou Ben Adhem ask you to

"Write me as one that loves his fellow men; 
Not a cloud to be seen, the great fat moon at its fullest, the stars brightly twinkling, the voices of the night and the sighing breezes lulling you to the sleep, you have richly earned by a day's sport, that some would call hard work. Whatever name is given it, you desire your undisturbed night's rest, and as you roli your blankets around you, taking a last look at the cheerful fire, you are almost tempted to say that the discouragements and annoyances of the day, if there have been any, were only to pave the way for balmy sleep, but you do not say it, you are asleep too soon.

Out-stretched on a bed of hemlock-boughs, your feet comfortably warm by the big fire. dreams if you are a dreamer should be pleasant, snores if you are a snorer should awaken the echoes of the hills, and the early morning should find you up refreshed, reinvigorated, and ready for another day's sport or hard work. But per. haps you have been lying with your back across a stıck or an old root, hidden under your bed of 
boughs, and you are so stiff and sore you can scarcely move when you awake, though a few minutes will drive the soreness away. It is a mere trifle, but you had better look carefully to the bottom of the shanty and remedy its little faults in time.

There is another discovery that is almost invariably made too late. The shanty leaks. This discovery is usually made about midnight and during a heavy shower. You turned in leaving the moon and stars shining, wind the wrong direction for rain, but during the night it has shifted and your first knowledge of it comes when patter, patter, patter, fail the drops into your ear, spoiling perhaps some sweet dream of a darling you have left at home. You turn over only to meet your neighbor rolling your way to avoid a little stream that has been incommoding him. You pull your blankets over your head and find that they have already absorbed enough moisture to render them uncomfortable. It is only half-past twelve, the fire is out, the rain is coming faster 
and faster. You manage to worry through until the beautiful sunrise of the morning puts an end to your miserable waiting. What a mockery is the golden light of daybreak to you after enduring the horrors of a sleepless night. It seems to say: "Grood morning how'd you rest last night? Well, I hope. Looks like a pleasant day."

Patching your shanty and deluding yourself with the idea that it is water tight may be satisfactory and it is a good idea to enjoy until actual experience stalks in and you get wet. See to it that your shanty is secure and tight as possible and then take your chances and win or loose do not grumble and chalks up one against your vacation. It is only an episode of the glorious life in the woods.

Around the evening fire Wilgus rather monopolized the conversation and we conceded his claim. The chief characteristic, distinguishing him next to his laziness and love of whiskey, was a most decided tendancy to extravagance in 
every statement he made. The most matter of fact and every day occurrence concerning himself, assumed almost heroic proportions as he related them, but if one took the trouble to investigate, he would invariable find their size and importance dwindle away to less than inappreciable mediocrity.

"So boys," he would say, "you didn't have fuss rate luck yesterday. Well, I purpose having a hack at 'em myself in the morning, and when me and my old bamboo git to work, why the matter is, there is always some fresh meat in camp. Just all you want to eat and lots to give away. I tell you boys, I'll lift the fins certain."

* $* * * * * * *$ * $*$ *

"My habits, I'll admit, aint never been of the best, yet I never seed but one sick spell in my life, and that was right after my killing the big panther on Burnt Pint."

"Why, Wilgus, I never heard of your killing a panther." 
"You might have heard on it if you had lived up in these parts. They can all tell you about it up here."

"Give us the story about your exploit."

"Me and Hen Paygan was out arter a bear, and had been running purty much all over the deestrick hereabouts and struck Burnt Pint. You can see the place as you drive over Hog's Back, the other side of Bethune, coming this way. We was on the Pint, about four or thereabouts, in the afternoon, and Hen spied a panther just getting into its den, and Hen's fust thought was to git up and git the other way. ${ }^{3}$ Hold on Hen,' says I, 'let's git Mr. Panther.' 'Dang Mr. Panther,' says Hen, 'he'll git us.' 'Not much, Mary Ann,' says I. Says Hen, 'you can have him Mr. Wilgus, I don't want him.' 'I want him,' says I, 'and want you to help git him. 'I aint helping so much as I was,' says he. 'I aint leaving this place without that panther,' says $I$. 'All right, I am,' says he. 'Gro on then,' says I, and Hen left me like the durned coward as he 
was. Well, Mr. Panther, you are my meat certain, thinks I as I looked over my rifle to see that it was all right. I didn't have no knife or I would have went into the cave without the rifle and come to close quarters. I crawled in, on my hands and knees, about twenty feet, made a turn to the right and there was the cave high enough to stand up in. It was dark as night and darker. Nothing to be seen, but over in the other end of it, a pair of eyes shining which was all I had to guide me. Up came my rifle just as the panther seemed to spring towards me. Bang and the panther dropped dead at my feet. I didn't know where I had hit him till I dragged him out after a hard tug and then found the bullet had struck plumb betwixt the eyes. Well, I got help, borrowed a knife and skinned the cuss that night and you can see the hide at my house any time. That night, while thinking on my adventure, it finally struck me as being rather a skeery place to put a man in, and dang me, if I didn't begin to grow skeert and in 
five minutes I was all in a tremble, till the old woman says: 'Hallo, Wilgus, you have been histing some more to-day.' Nary a drop,' says I, and then I was too faint to say more. The old woman got me into bed and there I laid a month before I was fairly myself again. You see a man like me never weakens when there is anything like that to do. After its all over then comes the skeer if ever. That's the only time I was ever sick with all my knocking round."

"Wilgus," says Grey, " you are the most infernal old liar I ever heard talk. I have heard that story of the panther before. It was one of the Becraft boys that kilied it, and how you can sit there and claim the credit of it passes my comprehension."

"That's all right, Mr. Grey, I was only telling you how I would have done and how it would have effected me il I had been there."

"Yes, you would have left with Hen Paygan, or never been here lying like a dog."

"I guess I'll average as much truth as any one in these parts." 
"That depends. From your last yarn I should say truth with you is very accommodating and keeps out of the way."

"Do you mean to say I don't care for the truth?"

"I don't believe you 'hanker arter it' The old saying is, truth lies at the bottom of a well, and I think you must have thrown you portion into the bottomless pit and have never been able to fish it out again, even if you have made the attempt, which I very much doubt."

"You never yet caught me in a single lie."

"No, you bet your life I never did. Your lies are not single. They are all married and have large families." 


\section{CHAPTER VI.}

"From our gleaming pile of pounders, we chose the larger and the smaller for appropriate experiments. Then we tested our experiments; we tasted our examples. Success. And success in science proves knowledge and skıll. We feasted. The delicacy of our food made each feaster a îner essence."

THEODORE WINTHROP.

"There is a tiny weed, man, That grows far o'er the sea, man

The juice of which doth more bewitch

Than does the gossip's tea, man, It's name is called tobacco ;

'Tis used near and far, man,

The carman chews-but I will choose

The dantier cigar man."

In the Woods-Pleasant Companions-A Summer's Nooning-A Pipe of Tobacco.

$\bigcup \mathrm{P}$ again with the first faint blushes of morning. That's the time to strike 'em. Ripe fruit wont wait you know. The trout enjoy an early breakfast, for they are sober creatures and need no matutinal cocktaiı to create a fictitious appetite. They go to bed early, have no lodges to attend, no cars off the track, nor ferry boats aground, no man down town to see on "business," nor any of the thousand and one ailments 
benedicts are prone to manufacture to allay the incredulity of their too exacting spouses.

* $*$ * $*$ * $*$ * * *

Time speeds away unheeded. Our shadows on the water told us it was near noon, so paddling our rafts to the shore, we landed and prepared our mid-day meal. A large log served for a table, for such as chose to put on city airs and style, whilc cle.un white chips answered the double purpose of plates and tables for the more modest. Fresh from the water, and before the rich colors begin to lose their lustre, is the time to eat our trout at their best. As no epicure cares for clam chowder except on the seacost or where he can get a whiff of salt air to give the proper relish to the bivalves, as the circus is the place of places for munching peanuts, so the camp fire is the place of all places in which to get just the turn to your game. The trout hissed upon the dishes in the most appetizing manner, and right speedily were we eulogizing the merits of some of them which Giles had 
carefully dressed, salted, buttered and broiled, and a more delicious morsel never passed the portals to one's stomach. "We take and enjoy our share and say a Benediction for the whole."

This is solid sport and comfort replete withalmost endless charms awakening the happiest emotions. Life here is no dull monotonous current, no calm level where one has to practice a false contentment. There is enough to do for willing hands, pleasant sounds and voices in the forest, on the river by the lake for those who can hear, plenty to see for such as have eyes and know how to use them, though there be folks who "can travel from Dan to Beersheba and say: 'Tis all barren and' so it is and so is all the world to him who will not cultivate the fruits it offers."

Of all pleasures I have ever experienced, none can equal this with a few chosen friends, a brisk walk up and down the mountain sides, a pull on the lake, a plunge into the crystal water, a hearty dinner and a noon day nap under the shade of 
wide spreading trees, cheered by the smiles and beauties of Nature, dreaming fanciful day dreams, watching the silvery ripples on lake and stream, listening to the whispering of leaves, to the laughing of waters, to the birds singing mingled and multiplied songs without words, and trilling love notes in the fullness of their joy.

"Happy the man who has the town escaped

To him the whispering trees, the murmuring brooks,

The shining pebbles preach

Virtues' and wisdoms' love."

To those who love society but not crowds for pleasure, we say go wander over mountains and move through field and forest, where you need not trouble yourself about folly and fashion, where you can kick off the shackles of conventionalism, where there is no fancied superiority of one class over another, but where all honest and and pleasant people are "hale fellows well met," and mind you, there is no place so good. to study character, to learn the disposition, to detect the good and bad qualities of companions, for successfully disguising yourself is simply 
impossible. You will show your heart unconsciously perhaps, but surely be it in your favor or against.

It was not so very strange that after our lunch we drew from our pockets pipes and tobacco and were soon enjoying the pleasures they yielded and rioting in the charms of a perfect summer's day.

From amid the delicate foliage in the green recesses of the hills, beside the clear mountain streams, in shadowed dells and in the mid-day sun on towering pinnacles, the forest songsters warbled their sweet improvisitatıons. The lake like a huge mirror trimmed with evergreens, ripples into mimic waves and beats against the shore like a slackened pulse. The birch trees with their silvery bark and leaves,

"Most beautiful of forest trees

The lady of the woods."

Grows side by side with the towering hemlock as if seeking its protection. The spruce intertwines its dark green branches among the 
strong rough arms of the giant elms, Balsam and pine whisper soft nothings to the maple and the beech; the white ash and the black held sweet converse, one with the other, and over all the glorious sun sheds his rays and throws around them his bands of golden light. The whole world is harmonious in our eyes. This place is too beautiful for anything poor, mean or insignificant.

If "a pleasant day is the smile of God upon the deeds of good men," this world is not all wicked-there must be good in it, and men and women are to-day performing good deeds in His name and $\mathrm{He}$ is smiling upon them and adding jewels to the crowns they are to wear in the better land.

Long we sat and gazed upon the lovely scene that surrounded us, listened to the bird music, let the breath of heaven fan our cheeks and thought perhaps of our own littleness as we looked upon the great ocean of verdure rolling mountains high. 
An hour before dark we were again casting our flies on the ripples. When we gathered up our lines we had a fair exhibit of the speckled beauties. And now for another smoke before retiring. Among a party of anglers did ever one fail to notice immediately after a hearty meal how soon all were blowing blue clouds of fragrant smoke from pipes of every discription, briar-wood and meerschaum, bog-oak, laurel root and corn-cob, some crooked with graceful swan neck curves to the stems, some short and straight like an Irishman's clay. Very seldom is a cigar seen. The cigarette from far off Russia, the imported Regalia, the native Rappahannock, the adulterated Stinkarora find no abiding place in the forest camp. The pipe as the smoker's luxury reigns supreme. A little plankroad stock whittled from the solid plug and rubbed in the palms of your hand until it has attained the desired fineness and then sprinkled with a pinch of Vanity Fair, "lays over" all the deft roiling of the weed by either home or foreign 
workmen. Once lit and well agoing, a pipe of plug furnishes an afternoon's smoke cool and lasting. It has not the tongue blistering and throat parching qualities of the mild light weed that comes in paper packages and cotton bags.

It is the fashion to preach against smoking, its opponents arguing that it is injurious to the health, while it is injurious only when indulged in to excess, and so is drinking the purest, clearest spring water, or eating the best cooked meats and vegetables. It makes one nervous they erroneously state, while the truth is, there is nothing known to the medical profession more soothing than a pipe full of good tobacco, unless it be two or three pipesfull, and hardly any class of people smoke more than medical students and full fledged M. Ds. The pipe has worked no more mischief than the tea and coffee pot. Go ask your doctor if it has. It helps digestion, and of all my acquaintances and companions in the woods I have found, without an exception, that the moderate smokers invariably endure 
fatigue, intense heat and extreme cold better than those who do not use the vile? weed.

It predisposes the mind to philosophic thought. "He who smokes much thinks like a philosopher," The Mohammedan everywhere cherish and prize it above all other luxuries they enjoy ; the Tartar believes that tobacco smoke clears the head, strengthens the sight, brightens the mind. In the wigwam of the Indian its fumes arise with the smoke of their council fires. The grizzly bearded worker among the mines of Colorado, California and Australia, the rough lumberman in the forest of Maine, the blue shirted tars who ride the waves of the Atlantic and Pacific, the soldier in camp and field will all tell you that tobacco is the other staff of life.

It will make a stupid man brilliant and talkative, developing his conversational powers so every one should acquire the art of smoking as of all arts it is the most social. If you are indolent, a cigar or pipe will exite and prove an incentive to action; if you are weary it will rest and refresh you. 
Shortens life? well, perhaps it does. We will allow five years to be deducted from the life of a smoker, for every smoker will be satisfied to give that time, liberal as it is, for the privilege of smoking, while he does live. Old age! We once knew an old store keeper, as they are called in the country, who was never blessed with a rush of customers, consequently, he passed the greater portion of his time, between the calls for half a pound of sugar and a yard of sheeting, smoking his clay pipe. He had saved during his long life a very respectable property, and his children, men and women grown, seeing there was no probability of his shuffling off, were secretly wishing him "to that bourne from which \&c., \&c.," but of course did not wish to cut his throat, poison him, or shoot him, so two of the brothers, after learning in some manner how the old gentleman was intending to dispose of his property, agreed that the cheap. est and least criminal way to kill off pater famil$i a s$, was to reduce his rations of tobacco, and by 
mixing powder with it, stealing it, breaking his pipes, or plugging up their stems so aggravated and troubled their dear old father, that he began to lose flesh and confidence in the weed, for never could he fill up a pipe without something being at fault. So completely demoralized and nervous did he become, that in two months from the opening of active hostilities he was beneath the sod. That was twentyfive or thirty years ago, and he died a very old man; whereas had his smoking not been interfered with, he might still be living, too old to die and all from being a confirmed lover of the weed.

Pass that pouch this way Gould, please, for that yarn sounds tough, but it is true as tough; for during some little household jar or domestic unpleasantness, one of the brothers "gave it away." And learning to smoke, is it not a test of gameness, perseverance, industry and other cardinal virtues, with a reward in the shape of pleasures, unimaginable to the uninitiated, plea- 
sures not to be described, but to be enjoyed by those who have survived the horrors of the first boyish attempt.

"Fudge." If you are not a smoker, perhaps it is better, but I will smoke my pipe as a lady sips her chocolate, slowly and fondly, carefully blowing the smoke in a thousand fairy fantastic forms, for I love it and love to sit among the curling clouds as they wreath themselves around my neck, which they touch more gently and softer than could a lady's arm. Now, now, care. fully old fellow, stop your nonsense and fill up once more with the strong seductive Turkish; fill up

"The pipe which is so lily white,

In which so many take delight."

A few more delicate bluey rings we'll puff and say good night. 


\section{CHAPTER VI}

"And through its midst there ran a crystal flood With many a murmuring song and elfin shout, In whose clear pools the crimson spotted trout Would turn his tawny side to sun and sky, Or sparkling üpwards catch the summer fly."

The Palace Garden.

"Oh 'tis sweet to feel the plastic

Rod, with top and buti elastic

Shoot the line in coils fantastic

Till, like thistle down, the fly

Lightly falls upon the water, Thirsting for the finny slaughter.

As I angle

And I dangle

Mute and sly."

Fitz. JAMEs O'Brien.

Jessups River-Wet Feet and Tight Boots-Creek Fishing-Losing a Trout-Suicide.

W HEN the morning broke, it was with a hazy misty appearance as if undecicled whether to keep its sunshine for some other day and send us a heavy shower, or whether to lighten up and disperse the sun's rays broadcast, but it soon befriended us, for the fresh wind scattered the 
morning vapors and rolled away the sluggish clouds which had hung over us like a cold shroud.

After breakfast, while taking our top o' the morning smoke, we con over arrangements for the day and as a sequel to a rather animated discussion conclude to break camp and move to Jessups River. At eight o'clock we are on the trail, which from Spruce Lake to Jessups River is very plain and easy to cover, but the tramp from Piseco crossing to our camping place is very irregular, in fact, as Giles says, muchly mixed.

The river where we first strike it, is a rather diminutive stream, yet affording fair fishing. It grows rapidly in volume receiving the water of almost innumerable tributaries and where we make our camp, about five miles below the Piseco trail, it has grown to be a grand trout stream. Rapids and rocks alternate with stillwaters and alders, riffs, and quiet pools offer their treasures to those who seek them. It is real 
brook fishing, than which there is no greater sport for any lover of good Isaac Walton, and the art he so quaintly and eloquently describes. Lake fishing is all very well in its way, but it is lazy sport this standing on a raft or sitting in a boat, paddling from spot to spot where fishes "most do congregate," with not half the pretty views that charm the eye as you follow brook or river among the woods and mountains.

Now, before we commence fishing, let us have a little chat about wading. Do not wear any of the heavy high top boots, advertised to keep the feet dry, as they are all humbugs, but get a pair of tightly laced shoes, that support the ankles, the bottoms filled with large headed nails and if there be a hole or two in them never mind, as they will let out as much water as they let in ; besides a rill of clear cold water running around your toes and tickling the soles of your feet is a decidedly pleasant sensation.

If ever anything strayed away from its proper abiding place it is a pair of boots in the woods. 
No man who values his legs and feet ever ventures the second time on a fishing excursion when he has to wade the creek with his boots on. The first severe tramp causes two or three wrinkles to gather in the side of them and they soon begin their mission of slowly rubbing the skin off your feet. Some may like it well enough, but one season was sufficient for me.

You could hardly wish to see your worst enemy in a more miserable plight, than to see him of a morning trying to pull on a pair of boots he has thoroughly wetted the day before. The heel won't drop into position; it catches the counter and hangs as though in a vise. A piece of soap to grease the stocking and after much geeing and hawing and jerking, the painful operation is at an end until the next morning, unless you resolve, which is the most sensible thing you can do, to go to bed with your boots on and let your galled feet ache. The man who comes with the low heeled, broad soled shoes, pitches them off as he retires, and 
in the morning fairly jumps into them and finds them as easy as a pair of old slippers.

If, while you are wading the stream some treacherous stone, deceiving and tripping you, lays you mercilessly down in the water, wetting you from head to foot, do not allow your spirits to be dampened--that is, you are not compelled to drink your Bourbon without a slight decoction of Adam's ale, but you must not lose courage; do not growl and whine like an infant. Tread very carefully. Faith you will have to do so to avoid the Scylla of numerous eddies and the Charybdis of frequent boulders, the one strong enough, and the other slippery enough to upset a careless wader every ten rods of his aquatic saunter.

The very thought is shivering and chilling, some one says: Oh! you are horrified at the bare idea of venturing knee deep into the crystal water, you'll get your feet wet, you don't enjoy "feeling the first cold drop giving notice to your great toe that in less than two minutes 
your boot will be full of water," which invariable effects your throat giving you an irritating cough or cold, you are not sure-footed enough to go prowling among the cobble stones, feeling your way across and adown stream, an occasional misstep might scatter the water over your face, which to you would be worse than the attack of myriads of musquitoes. You relish water in a tumbler or a wash-basin, but dear, darling, delicate little tenderling, you wouldn't strike out like a true angler, wading the stream, even if a temporary wetting secured for your basket its overflow of fish. Undoubtedly you are a near relative of the woman who forbid her little boy going near the water until he had learned how to swim.

If so, and you are afraid of rheumatism, wet feet, cough and cold, remain in the house, smoke your pipe, read Shakespeare, Dickens, Hawthorne, Irving, go out on the lawn and play croquet with the ladies, only keep your feet dry, but for "all that are lovers of virtue and dare 
trust in Providence and be quiet and go a angling," for the love they bear towards rods, lines, and the game they capture, the sport and excitement of landing a lordly fish counterbalances over and over again their fears of ducking and drenching. Indeed, no fear or thought of ill. ness enters their minds, for well they know that a change of clothing and a little extra care after the day's sport is finished, will prevent it.

Down the river, a few rods below the shanty, we espied a lovely little bank, where we rest and arrange preliminaries. Surveying with sat. isfaction his rod, line and reel, examining minutely the leader and flies, Grey pronounces himself ready and stepped into the water. The Aly is dancing on the riffs, and woe to the greedy fish that sees and attempts to capture the decep. tive insect, for like Shylock, we are determined to have our pound of flesh, and unlike Shylock, we have it, for ere thirty and one seconds have passed, that insinuating combination of feathers and floss, artistically concealing a 
small piece of sharp pointed steel, has taken hold in retaliation of a biting, something whose struggles leave no doubt as to its identity. A few minutes and he is worked ashore. $\mathrm{He}$ is a fair fish, exactly large enough to convince Grey that his tramping and wading promise a satisfactory result and besides accelerated Storm's movements, for that youngman was still standing on the bank lazily busy with the inspection and arranging of his tackle.

"Ned, how is that for a commencement?"

"Grood enough! Indeed it's splendid, and you'll only have to continue doing so for an hour to fill your basket."

"It's doubtful if I strike so fortunately again in two hours."

"Yes you will in less than fifteen minutes. When Good Luck befriends a man she doesn't desert him so quickly."

"Well, here's hoping for a continuation of Fortune's smiles ;" and away go the flies alighting like a feather amid the slippery ripples. 
One for each of us as I'm a sinner, and Grey's of course the largest, but not a word spoken after we have well commenced the day's sport.

Is not this sport above all other recreation? To be on a trout stream with nothing to break the stillness save the ripples of the waters, the wind whispering through the foliage of the trees, the music of the birds, your own bosom full of quiet pleasant thoughts, in harmony with the scene, is almost the perfection of human happiness.

A careful throw in yonder pool, a pool so still and mirror like, that it reflects the smallest bird flying in the sky above. Here it is where quiet and caution are indispensable auxiliaries of success, so give good heed to Beppo's injunction to Fra Diavolo, and make no noise.

What a promising place for a big trout just. above that high rock. I know there is an old settler living close by and I shall try to scrape an acquaintance with him. He can tell me, if so inclined, such delightful stories of olden 
times, the sights he has seen and may possibly give me some points that will be of service to me in dealing with others of his tribe; so creep along quietly, as if it were a rich man's house you were breaking into. The gentleman trout is no lover of the rough boisterous dweller of the upper world. He likes the quiet sly devils of the Major Bagstock sort, "the de-velish sly."

Down goes the gay deceiver, out runs a few yards of line, ample testimony that the old gentleman is at home and communicative to a pleasant degree, but a gentle pressure of the thumb upon the reel awakens him to a sense of the dangerous visitor he is entertaining. A wolf in shcep's clothing has called to pay his respects, and our host gives us anything but a cordial welcome when the mask is torn off revealing our true character.

One moment please! As the boy remarked to his father, who was about to chastise him; "hold on a moment dad, and let's argy the thing." 
Come, come, you must not leave us so abruptly, and we will not take your hint to make ourselves scarce; there is too much brass in our composition. We are as impudent as Fighting Fitzgerald; you cannot even kick us out, al. though you may pull a mite harder on the line if you please. That was a glorious somersault, worthy of Walter Aymour, but it failed to dislodge the hook. You are heading for that fallen tree, that stretches its arms half way across the stream. Going to mix things and spoil my visit? We will give you a couple of turns to prevent that piece of strategy from being consummated. Yes, certainly, you may go down the stream aways, if it will oblige your lordship. The deuce! you are giving me a pretty chase, aren't you, you blackguard? How do you imlagine I can go splashing through the water at such a rate, when I touch the smooth cobbly bottom, nearly tripping myself at every step ?

Did ever heartless coquette lead love sick youth such a chase, only to desert him, when 
he imagined everything secure and rose colored? Did ever love sick youth feel more thoroughly disgusted and miserable than Storm, when chuckling to himself with anticipated triumphs, back to him came hooks and flies with naught upon them.

There is nothing in the world that will engender momentary thoughts of suicide quicker than the loss of a trout, after he has given your tackle and your skill an opportunity of testing his metal and resources. Your money may take wings; your sweetheart run away with some other and better looking fellow, but you go bravely to work to repair your fortune, you look around and find some other loving heart truer than the fickle one who has deserted you.

To be sure suicidal thoughts, suggested by ill fortune, at losing some speckled beauty, vanish in a trice, still they are present on occasions. When the heart is in a thrill of excitement, your pulse throbbing with eagerness, your fingers 
tingling, your face glowing and eyes sparkling in a feverish expectancy, to see your almost certain capture break loose. little wonder is it you entertain thoughts of self destruction. It shows your heart is in the right place. It is proof positive you are an angler in love with the sport. A pot fisherman would have dismissed him with no sigh of regret, just as he would have landed him with no glow of enthusiasm.

A Turkish or some other proverb says, " every fish that escapes seems greater than it really is," but Storm keeps within the bounds of reason by calculating this one's weight at one ton. Storm was always a poor guesser and felt like drowning himself when this trout broke loose, perhaps would, only he thought this was a pretty good world to live in, the best he ever saw, notwithstanding the petty annoyances one is subject to; besides drowning chokes a person, fills him up, wets him, and then there was his real estate nut disposed of in a manner that his children could enjoy the full benefit of it, election day was 
coming on and he had a vote to cast for his candidate. Last of all he thought of his wife, and waded ashore to wait for Senior's consolation.

When Storm perched himself on an old log, fond memory reverted to that magnificent fellow gleaming with purple and gold, who was not floundering in his basket, among others of his kind, but was having his jaws nursed by some sympathizing friend. He had resource to the weed, and gloomy thoughts were soon dispelled. 


\section{CAPTER VIII.}

"'Tis sweet to view the limpid waters dance, As o'er their pebbly bed they eager rush, Or in the sun's effulgence brightly glance, As through the mead meandering they gush;

Now ringing forth rich music, now all hush, While song-birds chant the ever varied lay,

From out the willow and o'erhanging bush ; $\mathrm{O}$, sweet it is to thread the blithesome way, Clad in an angling guise, to spend a happy day."

"The ruling passion of a Yankee born Is, to cut down a tree; the only use He thinks it made for-save, perhaps, to burn Or split it up into rails.

Down The River-Pretty Things-A Quixotic AtTempt -Discharge of Wilgus.

GILES and Wilgus were instructed to move camp about four miles down the stream, and have everything ready for our comfort when we arrived in the late afternoon. We calculated that after having a day's sport, the end of it would find us near home, thus saving us a wearying return trip, and besides, have at hand new fishing grounds for the morrow. 
Jessups River fills all the requirements for a perfect trout stream, and not the least important next to its finny treasures is its ram's hornedness. Its course cannot be too winding and tortuous, for we are ever looking forward to the delightful uncertainty of the surprise, the next bend in the stream will reveal, speculating on the probable characteristics of the picture it will present. · Angling up or down a crooked stream, renders one almost insensible to time or distance, and if one allows his love of the picturesque and beautiful in nature a loose rein, when he comes to his home thoughts he will find himself much further from camp than he had reckoned on. Keep your mental watch wound up.

Almost every rod presents a new picture and every one pleasing. Here towering rocks, almost hidden with their luxuriant growth of vines, loom high above our heads, here a wild tumultuous mingling of ponderous rocks and stately trees, with here and there a few clinging 
myrtles, while below at the water's edge, are the trunks of fallen trees, drippping and hung with the richest greenest moss, always moist with the pearly dew or the spray from the rushing waters. A little further down are trees covered with masses of lichens and boulders covered with moss, dropping the coolest and most pellucid waters; and the next bend in the stream reveals long ranges of shadowy hills, beautified by the dim haze of distance and bounded by others so high that they seem not more substantial or enduring than the clouds they pierce. Here the trees and rocks are masters of every inch of ground, but a little below they have generously given a space for the flowers to bloom down by the water's edge, where snow-white lilies bend their pale spotless faces toward the water, seeking like a pretty maiden, to catch their own reflection. Golden buttercups nod coquettishly at every passing breeze, blue violets peep upwards from among the grasses, and there are daisies too, and blue bells, 
and little pink flowers, the squaw berry and waving ferns. Just below, a large tree has fallen across the stream, over which the water pours forming a pretty falls. Down further is a miniature island, and just beyond a point jutting out into the stream, around which the water curls angrily as if maddened that any obstacle should interpose to prevent its free flow. Further on are more flowers, more rocks, more trees, sandbanks, shady pools, dense alders, each turn in the stream, showing a different picture, pretty, though sometimes rough.

It is not the prettiest things that are always, and to every one, the prettiest, for the homeliest things are sometimes the prettiest. A rustic bridge of rough rocks or unhewn logs, even if its roughness is unhidden from the eye by climbing vines and flowers, may be pretty. A quaint old fence, even of rails, may be prettier than one carefully constructed, leveled, plumbed and measured. What fun-loving boys or girls do not see more beauty in an old swing- 
ing gate, upon which they can ride imaginary races, than in one of the ponderous iron ones, covered with flowery designs? An old straw hat or bonnet thrown carelessly on their heads makes many a rustic damsel beautiful as a fancy picture, but place one of the latest style upon their heads and the transformation from beauty to positive ugliness would be complete. Where can you find a prettier girl than Fanchon in her rags? Pretty houses are sometimes no prettier than old tumble down barns or log-cabins or bark shanties. Don't you think the house you were born in, the prettiest and cosiest you ever saw? Yet, perhaps, it has no flower garden like the one opposite, nor tall shade trees, nor graveled walk, but only a narrow path in the middle of the potatoe and cabbage path in front.

Don't you think your little sister or baby, the prettiest and dearest in the whole wide world, even if the dirty little savage is now up stairs yelling like a Sioux or Comanche brave, with the scalp of a pale face dripping from his 
hand? Was ever one blessed with such a noble father or gentle mother as you, even if your back is still smarting with deserved pain inflicted by one or the other?

The trees you sported under, the old horse sheds where you played woolley and pompeysmash, the little pond where you fished with a bent pin and piece of twine, the brown schoolhouse by the village green, the shady bridge near the blacksmith's, where you sold the horseshoes and scraps of iron you were lucky enough to find, the old cider mill you used to visit after school and on Saturday afternoons, with your hands full of carefully selected straws, through which you sucked the sweet juices; are not all of these pretty yet, though your head is silvery now and your walk slow? Yes, they are pretty, and their roughness helps to make them so.

There are pretty spots on this creek, where we fished to day, and it is only the little flowers, the great rough trees and rocks and hills that make them so, and some people might see them 
every day, and yet pass blindly by and know no beauty in them. They can see nothing pretty or beautiful except in a shop window or a woman's face, and pronounce-, well, my friend, you cannot see what 1 am driving at, as I cannot keep myself on the right track, but am continually switching off; but I have been vainly trying to show how pretty some homely things are, and how often we see really pretty things and fail to discern their beauty, just as I have stupidly failed to clearly express my thoughts.

However, it don't matter. I see beauty in the woods, in piles of logs and stones, winding roads, gnarled trees, old barns, old fences, old friends, I care not how old or homely. I suppose it is memory, taste, association, that makes things beautiful and-and I guess you commence to wonder, this time in real earnest what I am driving at, but I could do better and elucidate the subject more clearly, only I am going "a angling" to-day and cannot spare the time, 
so I will drop line in yonder shady pool, and sce what will turn up. It ought to be a decent sort of fellow, for it's a fine home for a fish.

Can't I throw a fly on the water without your troubling it? Come, I want you and you. There's enough for that little place so we'll wade further down the stream and make a cast in yonder current where one would hardly suppose a trout could live, yet, there is no better place to be sure of your game, than in the riffs where the water will almost take your feet from under you. Yes, we are wading the stream just as we described to you yesterday, with the water above our knees, and so long as you can keep your feet under you, there is no better sport; but, if you lose your balance and souse down in the water, ugh! only a pitiless laugh from any person witnessing your feet of tumbling is the consolation you are rewarded with, unless you can draw the article from a pocket flask.

What we are in search of, come fast as callers of a New Years. So we loiter along the edge 
where the stream is narrow, wade where it is wide, seeking out the most favorable places to cast a fly, finding them sometimes beneath the murky shade of the overhanging banks, at others in the swiftest currents and among the little white caps, and sometimes in the large still. waters that are too deep to be waded entirely through, giving us unpleasant trips around the alders that encompass them. There is little monotony in the style of angling, for every quarter of a mile offers the whole list.

Leisurely we trudge down the river, alluring to destruction all that are foolish enough to snap at our devices, and many such there were dashing through the swiftly running riffs, tumbling around the slippery cobbles, casting occasional glances upward to see if any delicate flies are within their greedy grasp, and we caused a migration to our baskets of some fair of form and beautiful to look upon.

Hello! here is the high rock again, where Storm lost the savage trout yesterday, after a 
grand struggle. Perhaps, the old settler has had his wounds dressed after disgorging the hook yesterday, been to his mother or his true love for a healing kiss, is feeling well and hungry, ready to respond to our polite attentions, eager for another bout with his ancient enemy. At all events, his antiquated old adversary is anxious to renew hostilities, and on goes a new hook, one carefully hidden beneath an alluring combination of colored feathers, on the same principle that bitter pills are sugar-coated for the delicate and sensitive tastes of sick little ones.

"You see the ways the fisherman doth take,

To catch the fish, what engines doth he make?

Behold! how he engaged all his wits,

Also his snares, lines, angles, hooks and nets ;

Yet fish there be, that neither hook nor line,

Nor snare, nor net, nor engine can make thine;

They must be groped for, and be tickled too,

Or they will not be catched what e'er you do."

Very well, Mr. John Bunyan, and

"If these won't make him,

The devil take him."

for Mr. Edward E. Storm, can't.

"L'homme propose,

Et trout dispose." 
Verily, it proved a quixotic attempt for the handsome old vetern was now a non-conformist, and would not take hold. He scorned every allurement. He was not to be coaxed, intimidated nor bull-dozed. Half a dozen different styles and courses were placed before him, but there was nothing in our bill of fare dainty enough. Raw nor well done, fat nor lean, would suit the long-headed epicurean old rogue, he remembered his yesterday's experience, cocked one eye upwards, and said :

"Though, this may be play to you,

"Tis death to me."

Gave his rudder a turn, set sail and was away. Not any for me, I thank you; appreciate your motions and notions, and motives and all that sort of thing, you know, my dear fellow, but cannot possibly, under any circumstances, assist in filling that basket to-day, because-because, well, because, I'll see you hanged first, and then I won't. Good morning. Ah, ha! here is one, and Grey has just put the finishing touches on another, a beautiful one, the pride of 
the family, a broad-backed pugilistic looking sinner, affording Grey a deal of fine sport before he mastered him, Storm was positive he had caught the largest fish, but Grey held up his last capture, and sang :

"No, no, no, not for Joe,

Not for Joseph, not for Joseph,

Oh, dear no; Oh, dear no ;

Not for Joseph, not for Joe."

Our arrangements and instructions regarding our new camping place, properly carried out, would have warranted us in expecting to find everything ship-shape, but on reaching it at evening, we found "confusion worse confounded," a very Grordian knot and bable of confusion, Giles had built, and furnished a new shanty with all the modern improvements, and Wilgus had put the finishing touches to it by felling a tree across it, while Giles was away doing some fishing on his own account, and the natural sequence was a hetrogeneous mass of spruce bark, tin pails and kettles, hard-tack and hemlock boughs, blankets and bacon.

"—_-in one red burial blent." 
Wilgus was seated on a convenient stump, growling at the luck and attributing it to everything but his own stupidity. It was the last blunder that broke Grey's patience, and he said :

"You are a constitutional blunderer and growler. In season and out of season, you must have your little growl. You would growl at your own shadow, if you could find nothing more substantial upon which to vent your spleen. The whole matter is, you are too energetic and enterprising in your laziness. You never lose your grip on indolence, and always manage to get the underhoid. Now, Mr. Wilgus, you must take a back seat and remain there very quietly, indeed, I put my arm around your neck and speak in the most friendly manner, and for your own good. I am heartily sick of this infernal and eternal fault-finding, stupidity and laziness, and now dear Mr. Wilgus, no more or it. In the morning you and your old bamboo follow the river down or up or cross-lots, I care not which, and you'll reach home all right."

Wilgus resigned next morning. 


\section{CHAPTER IX.}

"Thou pausest not in thine allotted task, $\mathrm{O}$, darkling river! through the night I hear Thy wavelets rippling on the pebbly beach,

I hear thy current stir the rustling sedge

That skirts thy bed. Thou intermittest not Thine everlasting journey, drawing on

A silvery train from many a woodland spring And mountain brook."

BRYANT.

“ But, Johnie, I maun, as ye'r frien' warn ye That it's no' the fly, nor the water, nor the rod, Nor the win', nor the licht, can dae the job, Wi' oot the watchfu' e'e and steady han', and A feeling for the business that's kin' o' born wi' A fisher; but hoo that comes aboot I dinna kin." Donald Macleod, D. D.

Sunrise-The old Whiskey Bottle-Strategic Angling - Life and the Stream.

"What envious streaks

Do lace the swerving clouds in yonder east? Night's candles are burnt out and jocund day Stands tip toe on the misty mountain top."

' $\mathrm{T}$ HE trees were brightening up, nodding a neighborly good morning to each other, and to the delicious zephyrs which were playing along the shore, wafting the sweet perfume of flowers and plants and the fresh smell of the 
river way up to the shanty, rousing every inmate from tiniest midget to mammoth Senior.

Up, up, crept the sun, its slanting rays dancing among the ripples of the river, dewdrops gemmed the leaves, sparkled on ferns and flowers which awaited the warm kisses of the morning to exhale their incense. Flowers, ferns and bushes waltz to the music of the winds, merrily whispering the while to the breezes as they pass. The birds began their songs, filling the deep woods with sharpest, shrillest music, which the mountain echoes returned tenfold, at first sharp and shrill as their copy, but the far away hills sent back their answer mellowed by the distance, and sweeter even than the little birds could make it. Grand masses of snow white clouds loom up like mountains of a new land. The dewy freshness of this soft, lovely morn gives promise of one of the loveliest days that ever gladdened a year.

This is the place above all others for a frolicing spree and a drinking bout conducted on 
purely hygienic principles. The pine scented air is so exhilerating as to be almost intoxicating. You can drink it in until there comes something akin to that feeling of perfect rest and content, that lays hold on a man when he becomes dead drunk and don't care a snap. Not a hair shall pull in the morning; you shal. awake at the rising of the sun, bright as a newly coined dollar, and find your hat still fits you.

If you are foolish enough to want the ordinary or plebian drunk go somewhere else, though some people do come here for no other purpose in the world, than to desecrate "God's first temples," and more's the pity that they ever find their way back to the proprieties of civilization. Such people always contend, that the first and most important portion of one's supplies should be whiskey, and lots of it, but, to silence any dissenting voice, would perhaps, acquiesce in adding a beggardly crumb of bread. Bread, according to their ideas and tastes, has about as much business with whiskey, as the 
walking stick of a kid-gloved exquisite, has with the main mast of an admiral's flagship.

A real lover of angling never allows his brains to be stolen away in such a manner. He respects himself, and loves his quiet sport too much. "He is cheerful and free from swearing and scurrilcus discourse." "He loves such sport as does not make friends ashamed to look upon one another next morning." A flask of good liquor in camp is absolutely necessary, but had better be smashed against the first rock, than taken except when taken medicinally, Honest Injun. If you must drink, have your rations regularly, take a draught of spring water. "It is the poorest in which to drink another's health, but, the best in which to drink your own," and, "charity begins at home," as the Indian philoso. pher, says: "Whiskey and water mixed, are two good things spoiled," but, the whiskey gets the better of the fusion, and the more water the better grows the whiskey 
"But, to our sport, around yonder turn in the stream are two immense rocks, protecting three sides of a deep, dark pool, shaded by venerable trees on the land side, and guarded against fly throwing, by a growth of bushes that defy any attempt to cast a hook in the ordinary manner, light enough to allure any of its denizens. Indeed, one might easily pass and repass the spot without for a moment, mistrusting that behind that tangled front of brush was a quiet pool, where for years and years no ray of sunlight had entered, where when wishing "to steal awhile away from every lingering care," the trout could hide and wait in safety for the food borne down by the current secure in the faith, that all the flies and bugs that ventured within the boundaries of his retreat were what they looked and no counterfeit presentments.

Grey stumbled across the pool a year ago, and brought two pounds of brook trout in one section from it. He waded up to the brush and rocks one day, carefully noted distances, inter- 
nal arrangements, the current, cut away a few twigs near the water, and in one minute had the whole place engraved "in his mind's eye." The next day he put a fly on the spot, with the above result.

"How did he succeed in accomplishing the impossible?" He repeated the trick to-day.

Grey went into the woods, found a piece of bark and placing a grizzly king upon it, launched it forth, watched it as it entered the current in front of the two big rocks, saw it sucked in beneath the overhanging bushes and disappear. In four seconds Grey gives a slight jerk, the slightest jerk upon the line, and the fly is supposed to be floating in the dark pool. Only one fly enters those almost sacred precincts. One fly, if it performs its mission, will suffice to test to the uttermost, the strength of your tackle and the degree of your skill.

You must be a graduate in good standing from the school of Isaak Walton, the school of " simple, wise men," to meet the first rush of that 
handsome devil who has taken your fly. The line tautens, you are almost conscious of having received a shock from an electric battery. Like a bull after a red bandana, the trout has rushed after the grizzly king with unbridled appetite. You must lead him to open water and that right speedily, else the two big rocks and the bushes surrounding his lurking place become dangerous allies. On the line comes a strain, such as you would not dare give it, save in this instance. It is your only hope. He may chaff the leader against the rock, he may take a half-hitch around some snag or tangle the line in the bushes to give your tackle the last ounce it will bear, and lead your captive out into daylight. Now, its a fair field and no favor. You cannot afford to be indolent, though your sport is called idleness by those ignorant of its requirements. You must be superlatively cunning, for the trout is an arrant rogue, and yet, how readily we forgive him his little foibles, when we have him on the end of a line or the prongs of a fork. 
Splash! splash! he rises, reflecting brilliant radii as he rushes to the sunlight, head, tail and fins, a whirling periphery. Cry in vain for mercy. Grey has hauled up the black flag; will give no quarter, will ask for none.

Whistle line, sing reel, there's music; bend pliant rod, there's an artist controlling you, a man true as steel, cold as an iceberg. Little difference to his nerves, be it trout, clam, shark or stick of wood, for he would manage one and all of them with the same intrepidity, dash and nonchalence. How the handsome fellow, gamest of the game, does fight. The trout, with all his cunning, his fierceness, and his intense appetite, is an aristocrat and a gentleman, the gentleman, par excellence, of the finny iribe, and it is the gentleman the world over, who on provocation or necessity, will make the best fight.

The more zeal one evinces for his favorite sport, the better his appetite. 
"I'm growing hungry in spite of the sport. That's our present trouble. There is a weak spot, and the symptoms indicate it to be in the vicinity of the digestive organs. Here is some hardtack, a cold chicken and sandwiches of pilot-bread, ham and potted beef. Hungry? Yes, that is what they call it. Either of us could have eaten a horse and his rider. Pitch in! There is plenty, unless you have an appetite like the man who won a match by eating a pig and an apple pie.

Did ever luxurious ottoman, unless there was a young lady to share it with you, afford a more inviting seat than this mossy bank, with one of the prettiest trout streams in the world flowing at our feet, grand old woods at our backs? Not a cloud to be seen in the transparent air, nothing but the sky above and the foliage below, through which plays the golden sunlight, casting shadows across the stream that winds its course irregularly between the hills and over the rocks, quietly and noisily, merrily and sul- 
lenly, carelessly and carefully like a spoiled child, ever changing its moods.

How like human life is this stream, now clear and sparkling as diamonds, flowing noiselessly as a child's sweetest slumbers, when angels guard its cradle, now murmuring and every murmur melody, every ripple music, now rushing on happy and free as playing children, laughing as it rolls over the slippery cobbles, eating angry scollops beneath the banks, wearing slowly but surely its way under the trees and exposing the grotesque frame work of their roots, which it has washed so white and clean, dashing over and around rocks, zig-zaging its way among fallen trees and then it pitches over seme huge rocks, groaning as it falls, the tears trickling down the outer edges and falling into the deep water below. On it goes through whirlpools of trouble and danger, now groaning loudly, now subsiding into silence, mingling with the shade, rushing, rollickingly out into the glorious sunshine, as though it loved the warm kisses of the summer 
sun, dancing to its own wild music, the little diamond crowned wavelets chase and court each other like living things. Idle enough it was, careless in the sunshine, lazy as it ran where the dark shadows are thrown across. 'Twas the merriest of merry streams, whether it sang tinkling like silver bells in the sunlight or whether it dreamed in the shade by waving ferns and clustering alders.

Here wearied of its journey, it widens out into a lake-like expanse, quiet and silent almost as death, then gaining new life and strength from its sleep, it dashes with renewed force, sailing majestically away, swallowing here and there a tiny rill from the mountain side, until it is itself swallowed up and lost.

Laugh and cry, complain and rejoice, hush, shout, peace, brawl, wayward stream, "'twas ever thus, since the morning stars sang together," and so 'twill be when we have landed our last fish, reeled up and crossed the dark river into the heavenly light beyond. 
High up in the trees, rocking themselves on the swinging branches, the birds pour forth their cataracts of song. Here and there little specks of sunlight sleep upon the ground, dotting it with golden shapes, while occasionally as the wind gently moves the leaves a light little fellow will jump to chase its playmates and run riot all around. The bird music, the hammering of a wood-pecker, the drumming of a partridge and the chat of an idle squirrel impatiently waiting for us to move, that it may feast upon the crumbs which have fallen from our table, and the murmur of the river, are the only sounds which break the impressive silence.

Throw the bones away, brush away the crumbs. That was an enjoyable little lunch as luncheons eaten beneath shade trees, by flowing water and growing grass, ought ever and always to be, even if the contents of your larder are plainest of the plain. You want no farinaceous puddings and fancy cakes or confectioner's knick-knacks, but a thick slice of Indian bread, a 
slice of sweet ham, and from time to time a swallow of cold water from a mountain spring, will make a meal not to be despised by any hungry man. Give your imagination a little scope if you are at all fastidious in your tastes and nothing can be more palatable. Here in the woods there is no need of being so particular as the starving men who refused a proffered cucumber, because it was crooked 


\section{CHAPTER X.}

"It is a sultry day; the sun has drank The dew that lay upon the morning grass;

There is no rustling ia the lofty eim

That canopies my dwelling, and its shade

Scarce cools me."

" Here we go up, up, up,

And here we go down, down, downy ;

Here we go backwards and forwards

And here we go round, round, roundy."

Old NuRsery RHyMe.

"'Twixt the fir-tree skirted ranches,

Where the Rattling Run doth shine

We erect out hut of branches.

Roof of birch bark, wall of pine ;

Floor it with the boughs of saplings,

Fragrant, sof: as couch of kings,

Rioting in forest pleasures

And the sleep that labor brings.

Gento C. Scott.

A Warm Tramp-The Upper Stillwater and High Falls Our Shanty-A Long Night.

THESE are samples of the days we spend on Jessups River. We fish it from the Piseco Trail to the old military road, and beyond almost to Indian Lake. Then, back to the road, where we leave the river and go to Sturges at 
the head of Lake Pleasant. From there we wagon it to the head of Piseco Lake, sail to the fort and walk a pleasant eight miles to Becraft's. Again, into the woods on the trail to the Upper Stillwater. Now, we meet old Mr. Corkscrew himself, disguised as a trail about ten miles long, having more twistings, turnings and angles, than any geometrical problem, but, "to Indian eyes, I sometimes think that even a humming-bird leaves its trail in the air," and our guide familiar with every step in the vast network of the forest, leading us, we zig-zag our way around wind-falls, conquer the difficulties of precipitous descents, hang by our teeth, as we climb over rocks and prostrate trunks, tumble up hills, the uphillishness of which approximates the perpendicular, with perhaps, a slight inclination towards us, pull like draught horses through soft marshy places too extensive to be flanked, though there are times when the longest way round is the shortest way home. 
Tripping up and falling outstretched, the trick of some treacherous root half hidden or more, beneath last year's leaves, hats lifted off and deposited on the ground just behind us as we pass under the low branches of some young tree, are only a few of the petty annoyances with which we contend. Here, a noisy brooklet to be crossed, affords us grateful invigorating stimulant, bracing us up and preparing us for another stretch.

Warm? we almost wished our lot had been cast for that day, at least, in Alaska or Siberia. Such a day it was that one might well wish with Sidney Smith, that we could "take off our flesh and sit in our bones." Hardly a breath of air stirring, and what little there was, seemed to come from a dry brush heap.

To many, the hard tramps experienced in reaching the different lakes is a serious, almost insurmountable barrier, protecting the trout to a greater extent than the game laws, but our quartette value highest whatever is most diffi- 
cult of attainment, and, we firmly believe, the tribute we will compel the Stillwater to yield, will amply compensate us for all present perplexities and discomforts. Though an intricate trail to follow, "'tis a long road that has no ending," and after a weary tramp, the Upper Stillwater stares us in the face and smiles a welcome, or looks bright enough to tell us that our coming is propitious.

The Upper Stillwater is about two miles long, varying in width from two hundred feet to ten feet or less, and in places the alders on either shore almost meeting across the water, leave barely space enough through which to pull your raft. From no one point can any considerable portion of the stream be seen, as its turnings completely shut out any extended view, but, each turn reveals a pretty picture. There is scarcely any preceptible motion to the water, and your raft will always go with the wind. 
A mile or so above the head of the Stillwater are the Walton Falls, which are among the highest in the Eastern States. They are so high, you have to look up twice to see the top. The best way to see them, is to climb to the top and look up. An accurate measurement of them has never been made, but three hundred feet will not more than cover then, and most people would calculate their height at nearer four hundred feet. The volume of water flowing over them is not extensive, except during the spring floods when the face of the falls would show a width of sixty feet. During our visit, about twenty feet was the breadth, and it took the form of what is known as the Bridal-vail Falls. Standing by the bottom of the great deep pool and looking upwards, one can only see about half the distance up, as the immense rock over which the water tumbles is shaped like a billiardball, and completely shutting off from view the upper half. 
"Coleridge was admiring a water-fall, and overheard a man near him, who said: 'Majestic.' The poet turned to him, and said: "That is the very word.' 'Yes,' continued the admiring rustic, 'it is jest the purtiest, majesticest thing I ever seed.' He had the soul to admire and enjoy it, but rhetoric was not his forte."

It is a severe climb to reach the top of the falls, but doubly repays the effort by the grand picture spread out before you, a wonderful picture from the hands of the Master Artist. Far away into the dim distance, the meeting place of earth and sky, the forest was unbroken far as the eye could reach, the green waving trees claim dominion. Pile on pile, the spruce and hemlock, bearded hills so richly and unsparingly clothed, giving birth to innumerable streams and springs; dreamland hills, they seemed, looming up in mistiness, almost spectral, barely discernable in the hazy distance, range above each other, hiding their heads in the clouds and forming one grand waving sea of verdure. All 
other forest views we ever beheld dwindle into insignificence, in comparison. Of the kind, it is one of nature's grandest spectacles. Surely, the world is a picture-book, God the artist, and here, where there is so much loveliness and grandeur, with so few to behold, we can well believe, that if " man is distant, God is near."

Half way between the falls and the Stillwater are the ice-houses, down deep among the huge rocks that have fallen from the face of Bluff Mountain, and where, at any season of the year, one can procure all the ice he requires for camp purposes, and, if so inclined, indulge in a snowballing bout, for he can find ammunition enough to supply a district school. On the top of Bluff Mountain are the eagle's nests, where, if you are unpatriotic enough, you can bag the royal bird.

A downright clever act it was in the previous occupants in the Stillwater shanty, and deserves its reward, for tired and hungry when we reached our journey's end, we found enough 
wook cut. for the night, pails and pans were hung up all in good order, the shanty clean with a nice bed of bougbs, and everything in as tidy a shape, as if some model housewife had had control of affairs. The shanty itself, was built of nicely trimmed boughs, and well covered with wide pieces of bark. According to Grey's measurement, it was six feet by seven, while Grould made it seven feet by six. Its size was the only objection. If five averaged sized men were to occupy it at once, they would be "Snug, Ass a bug, In a rug."

if not snugger; and we made a rule, that if any one woke up in the night and wanted to turn over, he was to yell "flop," three times. "Flop," to wake up the others, "flop," to make ready, and "flop," to turn over. The third "flop," meant business, and if one did not hear it he might feel it, by feeling somebody's elbow caroming heavily over his nose, or a knee thundering against his stomach. 
The smooth bark inside was scrawled over with absured caricatures and bonmots, every man who registered his name having given a specimen of his artistic or poetical abilities, which ever way his genius dictated. One scene represented the sun full-faced, with a thumb at its nose, wagging four fingers at two men fishing from a raft. Another represented a trout pulling a man out of the water. The only poetry we could decipher, was an extract signed Tennyfellow, which read thus :

"Blackflies and musquitoes,

Up hill and down,

Thunder and lightening,

To old John Brown."

Grand, right royal sport it is, tempting the cunning trout to partake of the delicate deceptive lures, man's inhumanity has invented to decoy them from their chosen retreats, to forsake home and friends, leaving behind old companions and associates, deserting the scenes of trouthood, making the greatest possible sacrifice, that of their lives-to gratify a morbid 
curiosity, man's amusement and three square meals a day. Great, magnificent, grand right royal as the sport might be, Senior and Gould were too grandly right royally tired out to partake of any exercise save filling their pipes and stretching out on the downy boughs of the shanty, leaving Grey and Storm to catch the supper.

There were three rafts at the landing, all in perfect order, with paddles, poles, anchor cords and seats. Senior and Gould fell asleep, and did not awaken until Grey and Storm returned with thirty or forty small trout fresh from the water.

After supper, the usual rubber of whist. The primitive hour of our forefathers for retiring, eight o'clock, is strictly adhered to, and that sensible old fashioned country hour finds us between the blankets courting the drowsy Grod.

As Storm rolled his blanket around himself, he prayed if ever he did, that this might not be a night of such pure and unadulterated misery 
as the tirst one he ever passed in this same shanty. It was a June night, and murky enough to a draw million and one musquitoes and midgets to the shanty. Frank Squires, a little boy of fourteen, rugged, brave and intelligent, was Storm's companion. They had tramped from Becraft's in the forenoon, fished all the afternoon until dark, and wet, tired and hungry came back to the shanty, had supper and retired early, anticipating a snoring good sleep. No sooner had they stretched out, than sleep claimed them, but could not make its claim worth a cent, for down came the fierce musquitoes and midgets in battallions innumerable. They may have slept a half hour, and that finished Mr. Morpheus. Storm arose and made a first class smudge, but bless you a smudge was the delight of their hearts; you might as well have attempted to smudge the gentleman with the cloven foot. At ten o'clock Storm and Frank arose again, fried a pan of trout and after eating them, had a smoke, and again tried to 
capture a forty winks of sleep. Frank put his feet and legs in a bag, tied up his head and face, but all to no purpose. At eleven o'clock Storm asked: "What shall we do the next hour, Frank?" I think we had better swear a little or make a pot of coffee," and the glorious moonlight was shining upon the unruffled waters and making sport of our misery.

The coffee was made and downed. Still, the musquitoes buzzed lovingly.about their ears, and, as though that wasn't enough to make them aware of their presence, joined with the midgets in levying contributions of royal blood to satisfy their desires, until Storm and his companion felt as though they were in an inferno, expiating some henious offense. At midnight came the all important question again: "What shall we do the next hour, Frank." "Gret up and cook a good square supper," and the moon with her attendant handmaids, the silvery stars, smiled down upon the great unbroken forest. After the midnight supper, they laid down again un- 
til nearly one o'clock, but sleep was out of the question, so they hustled around and reveled in the indiscriminate slaughter of their Liliputian familiars. 'Twas worth a king's ransom to let one escape, for when one of those diminutive devils, a midget, succeeds in effecting an entrance through your clothing, he means war to the death. There is no surrender on his part. He is game as a thorough-bred fighting cock, and somebody has got to travel, and if you leave, he will go with you, so go for him lively, where you are, divest yourself of your shirt if needs be, and warm him hot and heavy. He is far and away the toughest, hardest biter for his weight that ever tormented a mortal. Be not merciful, for if he escapes through your merciful feelings, he will hunt you again or worse, perhaps, he may open on some of your friends, and they may be unkind enough to use a little Billingsgate language towards you. One lively midget is enough for a full-grown, able-bodied man to attend to. You won't be thinking of 
your Sunday school class while he is feeling for you. You'll forget everything you ever learned at school, and remember only a few interjections and some miscellaneous phrases you picked up on the canal tow-path or street corners, and if ever you are justified in quoting them now is your justification.

"The darkest cloud always has its silver lining." And daylight put an end to the misery, and never did the dawning of morn receive a heartier welcome than it did from that pair of restless watchers 
CHAPTER XI.

"Trust to luck, trust to luck, Stare fate in the face;

Sure your heart must be easy, If it's in the right place."

OLD SONG.

"Among the plagues on earth which God has sent, Of ligher torment, is the plague of flies. Where wild America in vastness lies.

There diverse hordes, the swamps and woods infest, Banded or singly, there make man their prize."

Bishop of Quebec.

" Life with its features ever changing, And death with changeless face Joy. toil, and luxury, want and pa Pictured in motion, form, or stain, Found in the fire, a place."

No Luck-Black Flies and Musquitoes-A Short LectURE-PicIURES in THe Fire-"GluCk AUf."

" TIORTUNE favors the brave," says somebody, and somebody was wrong, else we were four as arrant cowards as ever stood on sole-leather, for all our attempts to coax the game we were after, proved abortive in the extreme, they were all away with their sweethearts, yet we did not lose our patience. 
"For patience is a virtue great, Therefore, we mun wi' patience wait."

Accepting the doctrine that "whatever is, is right," although our luck was worse than the Egyptian plagues for dark flies, light ones, gray, red nor white, all the colors of the rainbow, individually and collectively, would not suffice to tempt the speckled. We place before them coaxing morsels, that might be pronounced almost irresistible. Almost, not quite. Almost, another sad word. No combination of plain nor gaudy tints suited their capricious tastes. One might as well have angled for the polar star. The little scoundrels are not so blind this day, as to be unable to distinguish between a healthy bait and a sharp hook disguised with a few tiny feathers. It was just as Giles predicted, when he stepped out of the shanty in the early morning, and found the water glittering like a huge silver basin, with birds, waterbeetles and dragon-flies, dipping their wings in it, and dimpling its surface in their rapid and erratic flight. 
"No luck this morning," was what he said, and he made no mistake. There was nary nibble, and we must take the luck as men take 'wives for better or for worse, and the luck was bad enough. The boy who chased the rainbow in search of the pot of treasure, he believed, was hanging at its end, was fully as fortunate as we. We had bites, stout ones, such bites and then so many of them too, but they were invariably at the wrong end of the rod, and more of an aggravation than of pleasure. We never were in love, but have often been fishing and caught nothing, yet believe.

“' $T$ is better to have fished and failed,

Than never to have fished at all."

Towards the middle of the forenoon, we all came back to the shanty to compare notes.

"What luck Senior?"

"I haven't been doing anything so far, and have had very little trouble in doing it."

"My case, exactly. They don't appear to like my style to-day. How is it with you, 
Gould! Perhaps, you have been doing better.

Do they take hold?"

"What, the trout or the musquitoes?"

"The trout, of course."

"The trout? of course-not but I have had some glorious bites at the big end of the rod. See here, hands, face and neck, pretty well marked, I believe I would pass for a respectable sized trout myself, if I had the fins and so would you."

Black flies and musquitoes? Some of us had very thoughtlessly neglected to bring from camp our little bottles of prepared oil and tar, and had paid dearly for our forgetfulness. Grey, who carried a bottle with ointment, for two, had lost it and suffered accordingly for his carelessness or misfortune. Musquitoes and black flies? Yes, had you seen us from a distance when we shook ourselves, you would have thought there was a flock of wild duck taking their flight from our illustrious persons, only to return when the shaking was finished. 
They know a thing or two, do these little pests. When you have one or both hands free, they will sometimes perch on some convenient leaf and watch you with all their eyes, until you have both your hands engaged, when down they pounce upon you, and often, if you attempt to drive them away, it is at the risk of losing a fish, and they know it, or at least, act as though they do, so don't forget your bottle of oil and tar.

They swarmed around us thick as sand upon the sea shore, cut up their antics under our noses to their evident delight, buzzed, filling our ears with doleful sounds, smarted our hands, stung our cheeks, nearly slaughtered us, and, yet their bites were no worse, nor so bad, as the dreadfully monotonous songs with which they prepare their victims for the sacrifice. If they would go about their torturing in a quieter way, saying nothing of the death dealing doses they inflict, we could better endure the pain, but when they laugh at us and torture us to the tune of such heathenish music, it is cause suffi- 
cient to justify a man in striking his grandmother. Slaughter them on your cheeks, crush every bone in their bodies between the palms of your hands, build fires to smudge them out, and they will increase in proportion to the effectiveness of your smudge and butchery, so do not forget the ointment.

"Well, this is really discouraging," said Gould. "Our first experience on the Stillwater, is far from pleasant and cheering, and I hardly dare to hope for good luck, for fear of disappointment."

"Never mind our poor luck this morning, sonny," said Senior, "it is bound to change. Be like Mark Tapley, jolliest, when you have the hardest luck to deplore, Brace up and keep up your average. Be gay, when you have no more reason than this, to be downcast. Hope for a better day and better sport, that will make the darkest night shorter, sleep sweeter and more refreshing. If it be bad on the morrow, then be a stoic, and say, I'll take it as it comes. 
That's the shepherd of Salisbury Plains. Take it as it comes, my dear boy. The good and bad things of this world are strangely mingled, and he is happiest who can meet either with composure ;

"Come deaf, or come blind, or come cripple:

O come, ony ane o' them a'!"

let your countenance be expressive of mirth and hilarity, make it a perpetual protest against gloom and fish or no fish, let the flowers of pleasure unfold their petals on your face, and let the rollicking ha, ha, bubble up from your heart and overflow at the lips, like the gush of a summer's rill. While no human happiness can be complete, while there must be some element of sorrow mingled with worldly felicity, some-",

"Oh, Senior, go hire a hall and advertise yourself. I am going to get something to keep off these confounded flies, take a drink and a bite, and give the trout another chance to try my tackle this afternoon." 
After a hearty lunch, a quiet smoke, and a general annointing of our faces with the tar and oil, we make for the rafts once more. Storm and Grey paddle to the upper end of the Stillwater. They are to fish back until they meet the other raft. After awhile, the fish come to see us, and such sport as we enjoyed is sport always to be remembered. Grey had one exceptionally large trout, for this place claim his closest attention by his desperate rush, and away he went. Then, two came to the edge of the raft, did not like the appearance of things and refused to tarry. Meanwhile, four beautiful specimens of their kind had rewarded Storm's patience and virtue, when Grey's luck underwent a change for the better, and he captured any quantity of microscopic little rascals, almost as big as oats, just the size to put in milk for children.

As the Highland legions rose to the whistle of Rhoderick Dhu, so rose the trout to the anglers on the rafts, for in every part they were 
anxiously awaiting the hook and feathers to drop among them, that they might make amends for their unkindness towards us in the morning, and as one after another rose to sink no more, we made the woods ring and echo with our joyous and continued hurrahs. There was no let up, as we fastened our rafts to the bare arms of a venerable tree, lately deceased, that had fallen into the water, there was nothing to mar the happiness of any, until Grey saw a fair sized trout which had been admirably handled, suddenly disappear between the logs of the raft, having unhooked himself just as Grey was ready to do the agreeable for him. It was a day of forgetfulness. We had neglected to bring a landing-net and this fish could he have been saved, would alone have well repaid us for the little extra trouble of carrying one. A person should never fish from a raft without having a landing-net. In fishing from a boat it does not make so much difference, but, even then, it sometimes plays an important part, occupies 
but little room among your baggage, and adds scarcely any weight to your load.

A half hour before sunset, we were all fishing in the wide part of the stream near the shanty, all enjoying the sport, all capturing their full share of the game, and never did the crooked pin and piece of twine fill the heart of an urchin with keener delight, nor the most enthusiastic angler appreciate the fishes' favors. All of us were as contented as the coatless and shoeless country boy, who sits upon the bank of a muddy creek, awaiting the bob. bing of the float that detects the presence of some greedy little sucker.

To the shanty we plod our weary way healthily tired out, hungry, thirsty, sunburnt, almost fly blown, yet happy and cheerful, though not loaded down with a superabundance of game. Though our baskets had been heavier, our hearts were never lighter. A dozen respectable sized trout, and some small ones sandwiched between, in each of our bas- 
kets was satisfactory, and we were well enough pleased with our last two hours' sport, to forget the discouraging prospects of the morning.

The fire is burning brightly, and such generous humane soul and body cheering oldfashioned fire that would, in a night, consume enough wood to keep a poor family supplied with warmth for a whole winter. You could have roasted an ox at either end. Within the shanty all are gathered. Gould and Senior, complacently pulling away at their pipes, smoking philosophically and contentedly. About five feet ten of Grey lie stretched out, boots towards the fire. Storm with a packbasket for a seat, his elbows on his knees, his face in his hands, was watching the pictures and images among the glowing embers, though he could not keep track of half the fanciful forms that flitted but an instant in iife.

Forms and shapes of every description, some obscure and dim, others plain and distinct, 
seemed coming and vanishing in the air as each succeeding blaze shot upwards. First, a crowd of merry school children let loose from the study room; they are gone and a funeral procession follows with a shrouded coffin, plumes that waived like torches, the bowed figures of mourners; now a tournament as in the olden days of chivalry, with flags and lances and battle axes, proud horses carrying their riders through the thickest of the fight, grim figures playing hide and seek, ugly imps chasing each other through the crackling embers, mothers bending over the cradles of their little ones, cats and dogs and wee mice, changing into beautiful damsels, clusters of purple grapes, baskets of rosy peaches, apples turning to ashes, garlands of flowers, ships with sails bellying to the hot wind, old feudal castles and grand cathedrals, palaces, high towers and pleasant pictures of fairy land, all changing at every breath. Our huge fire streamed heave:1ward, roaring loudly as "the merry logs of 
Algidus," casting up clouds of sparks in the air. Now and then, some bright wayward little scoundrels would start into the thick woods and chase each other until they were tired out, leaving the old folks to growl and snap in the flashing flames.

Storm dropped from the pack-basket, Grould's tobacco was burned out, Senior could not draw another whiff of smoke through his pipe, none of us could keep our eyes open, and all were soon plunged into unconsciousness, sleeping the sleep of tired men.

We remained at the Stillwater a couple of days longer, gave it a thorough whipping and despoiled it of some of its handsomest treasures, and put back to Becraft's one Saturday afternoon. Before we took the back track, a night's wood for the next comers was piled up near the fire place, the pans and pails we found when we came, were washed and hung within the shanty, and all of us left wishes and hopes that those who followed us, might have such pleasures as had been meted out to us, and we charcoaled upon the shanty sides the famous greeting of the Cornish miners-" Gluck Auf." * 


\section{CHAPTER XII.}

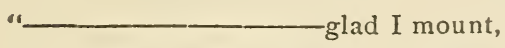

Into the open air grateful the breeze

That fans my throbbing temples; smiles the plains,

Spread wide below : how sweet the placid view.

But, Oh ! more sweet the thought, heart-soothing thought,

That thousand and ten thousands of the sons

Of toil partake this day the common joy

Of rest, of peace, of viewing hill and dale, Of breathing in the silence of the woods, And blessing Him who gave the Sabbath day."

"The memory of Sundays gone, is the angler's best Sunday company, when he is alone in the forest."

W. C. PRIME.

Snoring-Sunday Morning-The Haunted ChurchDINNER.

IN the woods, Senior did not snore. Hemlock boughs acted as a quietus upon that accomplishment, but the hour he struck a bed, he gave his proficiency, in that respect, full play. After our return from the Stillwater, we retired early. The drowsy God soon closed our eyes in sleep, but what seemed the rumbling of distant thunder raised the heavy eyelids. 
The sound proved not to be thunder such as is the fore-runner of a storm, but nasal thunder, proceeding from the most prominent part of Senior's face.

It was the loudest and most thorough snoring that ever disturbed the slumbers of wearied mortals. Every note on the snorning gamut was touched and articulated, only as an artist could do it. There was no falsetto, but every note pure, true and artistic. He was marvellously equipped, especially, in the higher notes sounding them with an ear and precision that comes from years of assiduous practice. They might be emulated, but not surpassed. It was the complete triumph ot a wonderful organ. Though he might awaken the enthusiasm and secure the plaudits of an audience, the wonder was, why he did not awaken himself.

He had a variety of tones, of different degrees of power and intensity, with as perfect a control over them as Patti or Nilsson have over their voices, now deep, long, roaring as 
though they came from the pit of his stomach ; then short and quick, as if formed and shot out from the Adam's apple in his throat; shorter and quicker from under his eyebrows, dashing over the bridge of his nose, and the sudden spurt has apparently exhausted him, so he seems to bring up more deep dolerous reports from his paunch and hurls them through the house. Occasionally a snort, like the snort of a war-horse smelling the battle afar off, would make the gray moustache on his lip, quiver like an aspen in a hurricane. His lips stuck out as though to give the fairy of sleep a resting place, a foothold where it could stand guard over him; but bless you child, those snores were powerful enough to blow such frail beings as fairies are generally reported to be, far away to the happy hunting grounds of the red skins. We were sorely tempted to awaken him, and mourned the want of a patent clothes-pin to spring over his nose, but sympathy and good nature prevailed over the punishment he really merited, so we "let him sleep on." 
Heralding with gorgeous pomp the coming day, kissing the flowers with its golden light, making brilliant the diamond dew drops on clover and grass came the Sabbath sun. Birds load the air with volumes of melody. The Robin

"- - pensive warbler of the ruddy breast."

perched himself in the thorn apple tree near the window, and told us 'twas time to be up; swallows darted hither and thither in graceful circles, and twittered from their mud-houses so skillfully built beneath the eaves of the Jarns; the wee humming bird

"Insect bird of the glowing plume,
Fairy king of the world of bloom."

sipped the sweet treasures of the honey-suckle, and wooed the choicest kisses of the roses, fat, well-fed bees, hummed monotonously, bumped their noses against the flowers in search of thir breakfast.

"Tis for them,

Unwearied alchymists, the blooming world, Nectarious gold distills."

Butterfies challenging comparison with the colors of the flowers, balance up and down 
among the sweet clover and play in the sunshine; gossamer insects commenced buzzing and swarming in the light, squirrels, the saucy chattering little scoundrels, leaping from bough to bough, fearlessly sported and frolicked, and a few musquitoes trying to filch a meal from our arms and faces, made Senior stop his snoring, and the rest of us our dreaming; while the jingling of the bell told us "the wittles is up."

"What a snorer you are," said Gould to Senior, while at breakfast. "We were watching you last night, and it any other man can produce such an assortment as you, I'll shoot him."

"Yes, I know I am an adept in that respect. Once in my sleep I stopped snoring for fully ten minutes, and some persons in the house who knew me hastened to my room thinking I must be dead, and nothing but my commencing the concert again could convince them I was only sleeping. Since then, to prevent any unnecessary anxiety, I keep the organ going." 
It was to be an idle day with all of us excepting Gould, who, after much wrestling with himself, finally succumbed to his evil promptings, and determined to go with a half-witted Dutch neighbor of Becraft's as far as the Big Meadows and fish the stream down. The rest of us visited the old church near Morehouseville, with which is connected the following story :

"Years ago a Frenchman named Petchie, and his wife, prompted by some unaccountable freak, moved to these wilds when they were even wilder than now. He purchased from the State a large tract of land, erected a fine house, built fences, opened roads, and in various other ways displayed his enterprise and spirit. Others followed his example, and soon he had quite a settlement growing up around him. This church was built, and for many years he with his family and neighbors worshipped within its walls. Petchie had constructed it with his own means, and in the center of the graveyard, near the church, had reserved a little plot of ground, where he and his wife were to be buried. 
"For many years the settlement was a quiet, happy place, until at last Petchie 'took' to drinking, and one day while in a drunken fit angry words passed between him and his wife, when she stole away to the barn, and when found, had hung herself. The priest refused to preach the funeral sermon, and forbid her being buried in the plct reserved for Petchie, but Petchie's neighbors supported the builder of the church in his claims, and said 'We would have had no church had he not built it.'

"So strongly did they insist upon her being buried in the graveyard of the church that the priest was forced to consent, but when the burial services were concluded, he called the members together in front of the church, and, going to the door, locked it, and in an angry voice said : 'For this wicked act of yours, I lock this church and lock the devil inside of it. The key I put in my pocket.'

"The priest was never again seen in these parts. The superstitious congregation would 
never again enter the church, believing that the devil was really confined there, but gradually moved away, and soon hardly a French Catholic was left in Morehouseville.

"The Church is fast crumbling away. The rear, where formerly stood the sheds and outbuildings, is now a low, damp marsh, which seems literally alive with snakes and lizards. In front, surrounded by a dilapidated rail fence that even the horses and cattle instinctively shun, are Canada thistles, burdocks, milkweed and mulleins growing in the richest and rankest confusion. Where once was bloom and freshness, is now decay and ruin. The lilies and violets have ceased to brighten the little yard, roses no longer grace the walk, woodbine and honeysuckle climb no more to the eaves and twist themselves around the casements. The church has lost its white color, the doors and windowshutters their green. All is one dark, rusty wood color. Sun and storm are the painters now. The stone steps are slippery with moss. 
Jackdaws and crows nestle at night in the old belfry, and there the owls sleep until the sun is down, but no other birds come near. Within, the simple altar and oaken crucifix are wormeaten and decayed, almost ready to fall in eipces."

And here the droning wasp and bee

With cunning skill contrive their nests,

The spider trails its fragile web

Athwart the heavy oaken beams,

And constantly the death-watch ticks

Within the wainscot's dusty seams."

The sweet sound of that, Sabbath bell calling the good people to their morning devotions may nevermore be borne through the still air of that holy morn.

"And those whose voices echoed here,

Whose feet had pressed the church-yard walk,

Who shall of their long absence tell?

Or who their wanderings can mark ?"

"Their voices may be hushed for aye,

And feet that vesper never knew,

From weary walks in life's long day,

May have the gates of heaven passed through."

A few months before our visit, a party of ad venturous fishermen prompted through curiosity to view his Satanic majesty burst open the door. A lightning like whiz was heard, 
and a shadow passed out of the door knocking one unlucky fellow from the slippery steps. Whether it was really the devil or the whiskey, the fellow was known sometimes to carry, and the fact of his standing on rather a slippery place, that disturbed his center of gravity is not satisfactorily decided-

"I cannot tell, how the truth may be,

I say the tale, as 'twas told to me."

but read the morning papers, and from the accounts you will there see of murders, robberies and assaults, you will conclude that "Old Nick," is not locked up in a church.

It is said that school and church are hungry places. The walk to the church and back had put our appetites in splendid order, and Mrs. Becraft from her knowledge of our capacities had prepared one of her famous dinners. It was one o'clock.

"And then we heard,

That tocsin of the soul, the dinner bell."

The great oaken table covered with spotless linen, fairly groaned under the load of tame 
chickens and wild trout, flaky biscuit, golden butter and amber honey. There were no wines, nectar of the Gods. We were only poor mortals, and must be content with coffee, but such cof fee; almost the staff of life. The south wind breathing o'er a bank of violets has long been the poetic idea of voluptuous fragrance, but, to a hungry man it is surpassed, far and away by the mingling of the exquisite aromas arising from a coffee-pot filled with boiling and steaming Java or Mocha, and a frying-pan filled with juicy trout.

Chickens and trout beautifully hidden in their golden brown coats, were prepared with a delicacy that defied the skill of other cooks of more pretentions. The great china pitcher sweated beneath its icy load. We look with eager and surprised eyes upon the loaded table, and sight is pleased; our noses give an involuntary snift as though the smell was agreeable, and the words of Senior

"Be seated, and what shall I help you to."

fell like sweetest music upon our ears, Senior- 
was a perfect dinner-table surgeon. He handled the carving knife with a dexterity that would have bewildered an expert juggler. There were no chunks leaving the big dish, but every piece was cut thin, and even a tough piece he makes tender by carving it the right way. There is no splashing of gravy, no helping too much and disgusting the appetite, but only enongh to make one pass his plate for more. The dessert appeared and vanished in its order. The salad was so cold and crisp, that it sounded, while we were eating it, like the starting of a heavily loaded sled of a frosty morning, and altogether our dinner would have forced groans of agony from a dyspeptic, but from us it inspired nothing but contentment and inward satisfaction. There was a clean sweep of the table, and outside of the salt cellar, the pepper-box, the mustard-pot and the vinegar cruet, there was not left enough to bait a singlebarrelled mouse-trap. Everything else was dry. as the contribution box of a bankrupt congregation. 


\section{CAPTER XIII.}

"Hail to the shocking old straw hat, Second hand trowsers, coat and boots, Box of worms, lively and fat, All hail your hook in these old roots.

Careless man, Mad as bran.

Neither snap

Nor flip flap."

"We thank God, for these woods, these mountains, and these ever singing waters. They are not only the angler's Elysium, but the great medicine chest of nature."

GEORGE DAwSON.

"We plunge in the crystal, our sport is begun, Our line, where that ripple shoots onward we throw, It sweeps to the foam-spangled eddy below, A tremor-a pull-the trout upward is thrown, He swings to our basket-the r-ize is our own."

STREET.

Sabbath Breaking-Night UP a TreE-Forest LessonsFLY FisHING-GoOd Night.

YESTERDAY Gould went fishing with Becraft's Dutch neighbor, Jake Meyers. The Dutchman, to combine profit with pleasure, drove three or four cows over the hills and through the woods to the meadows, that they might fill themselves with the rich grass while 
he was filling his tin pail with trout. The Dutchman's lack of brains was more than counter-balanced by a superabundance of laziness. He was

- too lazy to dig more than three worms for his day's fishing, but being a good bait fisherman, he really needed no more, for after he had captured two or three fish he would insert the hook in the fishes' eyes, tearing them out, and repeating the operation whenever necessary upon others as he caught them, so that he always dug his bait as fast as he caught his fish. If his usual good luck was any criterion, the bait he used was as taking as any other, although he spoiled the appearance of his catch. Gould and his Dutch friend both paid dearly for their desecration of the Sabbath.

Gould returned during the middle of the afternoon, wet, scratched, tired, discouraged, repentent, and with the proverbial ill luck that attends the unsuccessful fisherman. At every step, splash went his feet, driving the water through his bursted shoes. He had lost half a 
dozen flies in the tree-tops, barked his shins, lost his pipe, and finally, when crossing the stream on a fallen tree, stepped on a treacherous limb that snapped under his weight, and before he could recover his equilibrium, down, down he went, his hat floated away in the rapids, the tip of his rod was smashed, his clothes torn, his day's sport(?) finished. The crowning misfortune consummating a merited punishment followed, when, flashing through his mind came Senior's unheeded warning and advice. Back to Becraft's he came in no very amiable mood, looking rougher and raggeder than any tramp that ever cheeked a summer's living. His mishaps, though aggravating enough, and deservedly so, were insignificant in comparison to the complaint we had from the Dutchman, and to which we listened while getting ready for our last day's fishing.

After seeing his cows commence their feeding in the Big Meadows he left Gould and started for Alder Creek, and fished there until he had 
his tin pail full of fingerlings. It grew dark early for a storm was coming when he retraced his steps towards the meadows, intending to drive his cows back home with him. He found all but one, and started them over the hill towards the settlement, and then returned for the stray one. Now occasionally a bear from the same hills will make a nocturnal promenade through the settlement, and as Jake had a mortal fear of them, nothing would have induced him to continue his search had he been wise enough to have noticed the indications of the storm that was brewing, and the slight possibility of a visit from a bear. It was dark when he was on the mountain top, a sprinkle-down came the rain. We will let Jake relate his own experience:

"You sees, I goes bake again for dot ret cow, shust pefore dark. I hade all odder cows but dot von, und she vas vay up der mountains somedimes. Vell, I had got shust a leedle vays peyont dot odder sides ven I heard a pell, but mine golly, it vas odder man s cow all der times. Mine 
cow didn't got no pell. Bumby der rains falls und crows so awful tark, dot was awful hart, you could no sees your fingers by your own eyes. Vell, I lose der leedle bath, und vas vandering arount und vondering vere I vas, und bretty * soon I sees von pig noise in der drees, und I tought sure dere vas a pear loose, so I climps me up a leedle dree youst as der pear comes snuffing town pelow. I climps up till I comes by a leedle limp not much vider as mine tumb, und I strattle dot leedle limp. Bumby der rains falls acain, und it schlides town dot dree I vas up mit und it comes schliding town, und der more vot it comes schliding town, der more tider vot I have to hold on mit der dree, und de vater runs town by mine neck und head und bake. Mine Golly ! dot vas hart, und me sidding on a leedle limp shust no vider as mine tumbs. How dot leedle limp did hurt. Town pelow vas dot tam shaggy pear at der feet of der drees looking und vatching of me, und afery minutes I taught he climps up dot dree after me. All night long 
when der morning preaks avay und der sun comes up mit its light, I sits on dot leedle limp not so vider as mine tumb. By golly! how dot leedle limp do hurt. Ven it vas sun up enough as I could see to der ground, by tam, der vas dot tam ret cow close by der foot of der tree und der drail not more as von feet away, und den I vas mat as everytings, after stradtling dot leedle limp not so vide as mine tumbs all der night. Mine golly ! dot vas hart, und I says odder dimes I go looks for mine cows und she no comes bake pefore tark she may go to der tuyfel mit me."

Leaving Gould repentant and Jake disgusted to condole with each other, Grey and Storm started down the creek. This day finishes our sport for the present. Our vacation has been "idle time not idly spent."

The days and weeks passed here as we have passed them are rejuvenating to the old man, and for the young man is laying the corner-stone of perfect health. The man who loves to angle, to 
camp out and knock around in the woods, finds it not only a hospital and a dispensary, but also a gymnasium, a school and a church. He studies nature in her varying moods, in sunshine and in shadow. Everything animate and inanimate which goes to create nature has for him a reason and a guidance. He learns the medicinal properties of plants, becomes familiar with ferns and flowers, and the sturdy trees. He learns the cry of the loon, the hoot of the owl, the notes of the blue jay and the cat-bird, and grows to know their habits. The west wind has its meaning and the east its warning, the clouds above their caution. The sighing wind, the ripple on the lake, the rustle of the leaves, whisper their secrets. The contraction or expansion of the clover leaves is a harbinger of rain or sunshine; the opening or closing of the thistle heads and the chickweed foretells of weather wet or dry. Even the smoke of his camp-fire restrains or prompts him. He becomes so intimately acquainted with the buz- 
zing musquito, the biting black $\mathrm{fly}$, and the minute midget, that they stick to him closer than a brother. He can time their coming to a certainty, he learns their color, size, age to which they attain, habits, number to the pound or bushel, number of pounds some exceptionally healthy ones weigh, length of claws, and other particulars concerning them that only scientists investigate.

This forest life, "this looking through nature to nature's God," makes the angler sympathetic, gentle, a Christian; and no wonder, for the unwritten book of God is always open to him, and insensibly, perhaps, he is learning some lesson, growing better and wiser, loving his fellowmen, loving the golden rule, which says, "Do unto others as you would that others should do unto you."

Down below the old bridge, Grey stepped into the water. He looked a perfect picture as he stood knee deep in the running stream, and gracefully casting his flies. His well fitting 
coat displayed to the best advantage his broad shoulders, while the basket at his side, the chequered shirt-front and wide brimmed hat becoming him perfectly, sdded a look of the true angler. Many and many a time have 1 paused from my casting, to watch his graceful motion as he dropped his flies fifty or sixty feet away, dropped them with the ariness of thistleaown, so lightly as to deceive even the grandees of the pool. It is the poetry of the gentle art. He is one of the few who never fail to conquer the usual impediments to fly-fishing, be it a high bluff directly behind him, a tree leaning over him, a contrary wind, or whatever obstacle the angler frequently meets. Plenty of good spots he finds that many would pass, pronouncing them impracticable from the difficulty of getting out line in that seducing manner the trout so love and reward.

We hear of fly-throwers who can place their stretchers on a maple leaf twenty or twenty-five yards distant, and no part of the line or leader 
shall touch the water. We have yet to see that man. There will be some part of his line on the water if he attempts throwing that distance, right or left handed, as circumstances required, Grey could get out as much line as any one could, slightly checking it before it reached the water, to prevent a splash and keep it taut. The leader properly dyed never alarms the fish. Then, setting the hook with an almost imperceptible turn of the wrist, the result of instinct rather than of reason, for quick as thought, quickly as the nerves convey any sensation to the brain, you have no time to think until the hook is fastened, for a trout displays an immense amount of energy and abruptness in his suddenness. After you have felt the electric thrill and know you have hooked something, then you can study the situation, and reason tells you how to conduct the attack.

Now, see just between those two rocks, and almost under the bank, Grey tosses his flies which alight soft as a shadow among the 
whirling eddies. But, an instant it rested lifeless, when a heavy swirl betokened how well it had performed its mission. A deft turn of the wrist, the sudden whirl of the reel, the lengthening line, the graceful curve of the rod, with now and then a momentary glimpse of the hand, some sides of a trout among the bright ripples. proves there is a dangerous customer to be dealt with. With lightning speed, almost the entire length of the line is unreeled, and at the first pause, Grey quickly tightens up, securing as much line as possible, when away goes the trout again, swimming in rapid circles, dashing down to the rocky bottom, and anon skimming on the surface, lashing the water like a harpooned whale, on a small, very small scale, breaking in every direction, up, down, and across stream, seeking for some vulnerable point, some weak spot through which he can escape. He seemed to grow more infuriated as life, and the line shorten. Every movement redolent of life and smacking of business. Never did demon strug- 
gle more desperately, but the fierce hook hangs with a tenacious grasp upon his jaws. His rushes becomes less and less dangerous. Slowly and surely he is nearing his fate, and with a last desperate break and a few spasmodic jumps, he turns on his side a defunct salmo-fontinalis.

Plenty of little fellows, a few good-sized ones captured back of Joe Lanes', and a couple of what the natives call "old hunkers" altogether, well filled our creels, so as twilight commenced to set in the woodland gorges, we reel up, climb the high hill, cut across the meadow, and reached Becraft's in good season. We arrive with weary limbs and voracious appetites. Falstaff and his recruits were a kingly crowd in comparison. Supper was soon ready, and we paid it a practical compliment. Tarrare never dined with a more devouring and devastating appetite.

The next move is to the front porch. Gould to smoke his cigarette, Grey and Senior to ex- 
patiate in glowing terms upon the brilliant days of our trip, and to keep mum about the unlucky ones. Storm to puff in silence over his briar-root, and regret that he had to go home to-morrow. We had caught our last trout, and there was naught left for us to do, but to talk, and think, and thank, for the smiles of fortune, and the blessing God has vouchsafed us in giving health and strength to enjoy.

The moon pourcd down its rays of ether light, flooding the trees, barns and fences, with silvery showers. Dew drops were clinging to the bushes, lilacs, on the clover and on the grass.

"All things are hushed, as Nature's self loy down,

The mountains seem to nod their drowsy neads.

The little birds in dreams, their songs repeat,

And sleeping flowers beneath the night-dew sweat."

In the holy hush of such an evening, wit:the moon and stars shining, and beautiful as angel faces, the storms of earth forgotten, we may feel that there is something of heaven, even in this wicked life.

As the bright evening star dropped its face behind the wooded hills, seeming to say goodnight, we wished each other a quiet rest. 

$(69)$ 



$-1$

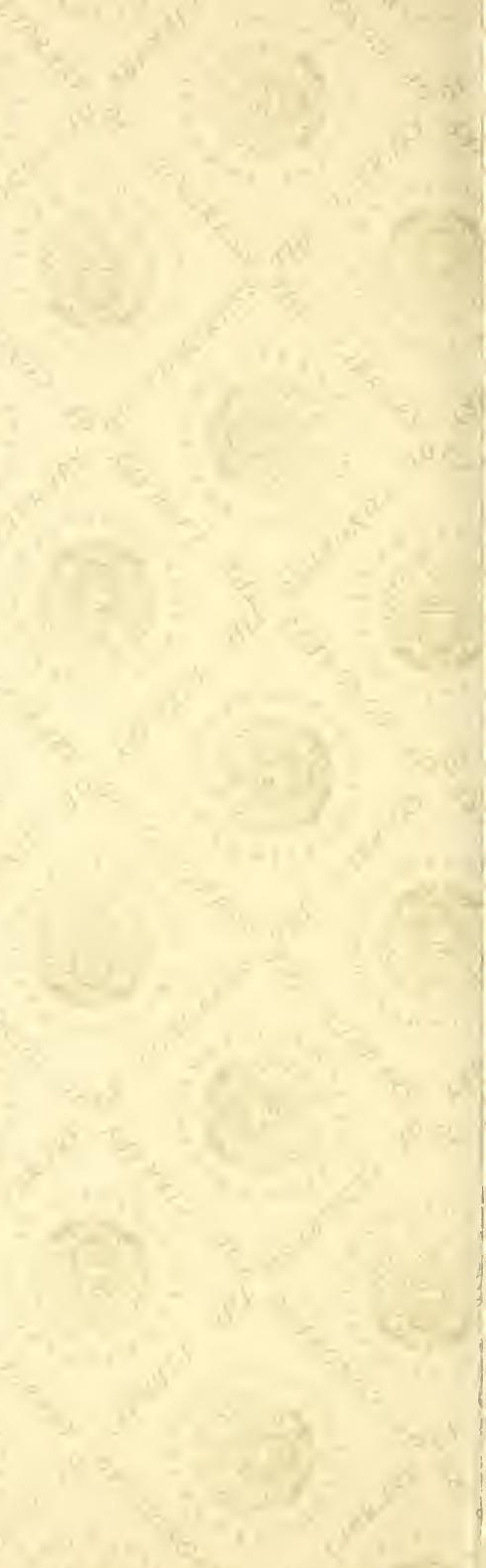





\section{LIBRARY OF CONGRESS ||||||||||||||||||||||}

